\title{
THE SYLLIDAE (POLYCHAETOUS ANNELIDS) FROM JAPAN (V) - SYLLINAE (2)-
}

$\operatorname{AUTHOR}(\mathrm{S})$ :

Imajima, Minoru

\section{CITATION:}

Imajima, Minoru. THE SYLLIDAE (POLYCHAETOUS ANNELIDS) FROM JAPAN (V) -SYLLINAE (2)-. PUBLICATIONS OF THE SETO MARINE BIOLOGICAL LABORATORY 1966, 14(4): 253-294

\section{ISSUE DATE:}

1966-09-20

URL:

http://hdl.handle.net/2433/175446

RIGHT: 


\title{
THE SYLLIDAE (POLYCHAETOUS ANNELIDS) FROM JAPAN (V)* SYLLINAE (2)
}

\author{
MiNoru IMAJIMA \\ National Science Museum, Japan
}

With 16 Text-figures

\section{Parasphaerosyllis MONRO, 1937}

\section{Type: Parasphaerosyllis indica Monro, 1937}

The body is slender and threadlike. The prostomium has two pairs of eyes and three antennae. Palpi are subtriangular and about as long as the prostomium. Dorsal cirri of the anterior region are long, slender moniliform; in the posterior region they alternate slender cirri and a large bulbous fusiform structure with a small terminal knob. Parapodia are conical and have a fascicle of compound setae with bidentate tip.

$$
\text { Key to species of Parasphaerosyllis from Japan }
$$

1. Bulbous fusiform dorsal cirri occur from the 4 th setigerous segment, each with a terminal knob $\ldots \ldots \ldots \ldots \ldots \ldots \ldots \ldots \ldots \ldots \ldots \ldots \ldots \ldots \ldots \ldots \ldots \ldots \ldots \ldots \ldots \ldots \ldots \ldots \ldots \ldots \ldots \ldots$ Pasphaerosyllis setoensis

1. Bulbous fusiform dorsal cirri occur from the 14 th to 16 th segiterous segment, each with two or one articuled $k n o b . \ldots \ldots \ldots \ldots \ldots \ldots \ldots \ldots \ldots \ldots \ldots \ldots \ldots \ldots \ldots \ldots \ldots$ Parasphaerosyllis ezoensis

\section{Parasphaerosyllis ezoensis IMA JIMA and HARTMAN, 1964}

Parasphaerosyllis ezoensis Imajima and Hartman, 1964, pp. 120 122, pl. 28, figs. a-h.

Parasphaerosyllis indica Hartmann-Schröder, 1960, p. 84, pl. 6, fig. 50. Not Monro, 1937, p. 273.

Collection: Shirikishinai, in 40-60 m; Matsumae; Onagawa; Seto; Noto-ogi, in intertidal zone.

Description: Specimens measure 4 to $6 \mathrm{~mm}$ long and 0.5 to $0.7 \mathrm{~mm}$ wide; they consist of 50 to 67 setigerous segments. The body is pale yellow and has no color markings. The prostomium is subglobular and has two pairs of reddish eyes. A median antenna with 35 annulations is inserted between the anterior eyes; lateral ones with 18 to 20 annulations each arise in front of the anterior eyes. Dorsal cirri of the first 13 to 15 setigerous segments are slender, moniliform, and alternate

* Continued from Part 4 (XIV (3), pp. 219-252).

Publ. Seto Mar. Biol. Lab., XIV (4), 253-294, 1966. (Article 19) 
long with 30, and short with 20 annulations. At setigerous segment 14 to 16 the dorsal cirrus forms a large, bulbous, fusiform structure terminating in one or two articulations. More posteriorly the bulbous cirri and slender, moniliform ones alternate regularly; and on most posterior segments their arrangement is irregular. Parapodia are conical and have a fascicle of bidentate compound setae with serrations along the cutting margin. The appendages of superior setae are longer than those on inferior ones. Acicula occur singly in a parapodium. The posterior parapodia have also two simple setae in superior and inferior positions of the fascicle.

Distribution: Japan; Red Sea.

Parasphaerosyllis setoensis $\mathrm{n}$. sp.

(Text-fig. 50, a-i)

Collection: Seto, in intertidal zone.

Description: A single specimen measures $7.5 \mathrm{~mm}$ long and $0.5 \mathrm{~mm}$ wide including parapodia; it consists of 97 setigerous segments. The body is slender and threadlike, and has no color markings. The prostomium is globular and has two pairs of eyes in trapezoidal arrangement (fig. a). A median antenna arises from the center of the prostomium; it is about 5.5 times as long as the prostomium, and has 35 annulations. Lateral antennae emerge from anterior margin of the prostomium; each is about half as long as the median antenna. The posterior margin of the prostomium has a pair of small nuchal lappets. Palpi are subtriangular and shorter than the prostomium; they are fused only at the bases. The pharynx is very slender and has a subdistal middorsal tooth in its inner wall. The proventriculus was not found. The dorsal tentacular cirri are about two-thirds as long as the median antenna and the ventral ones are about half as long as the dorsal ones. The first dorsal cirri are slightly longer than the dorsal tentacular cirri and have 27 to 29 annulations. The second are short, with 12 annulations, and the third are slightly shorter than the first cirri, with 20 to 22 annulations; they are slender and clearly moniliform. Each of the fourth dorsal cirri is large, bulbous, fusiform with a small terminal knob; the cirrophore is short and squat (fig. b). The next cirri are long, slender and moniliform with 20 annulations (fig. c); thereafter the bulbous cirri and slender, moniliform ones alternate regularly to the end of the body. Parapodia are conical and have a fascicle of bidentate compound setae emerging between anterior and posterior setal lobes. The appendages of superior setae are longer those inferior; the cutting margins have serrations (figs. d, e, f). Posterior parapodia have two additional simple setae located in superior and inferior positions; both are slender and distally bifid, with minute serrations along the distal convex part (figs. g, h). Acicula occur singly and terminate distally in a blunt tip (fig. i). Ventral cirri are digitate and extend slightly beyond the parapodial lobes. The pygidium has two long anal cirri.

Parasphaerosyllis setoensis is allied to $P$. ezoensis Imajma and Hartman (1964) 


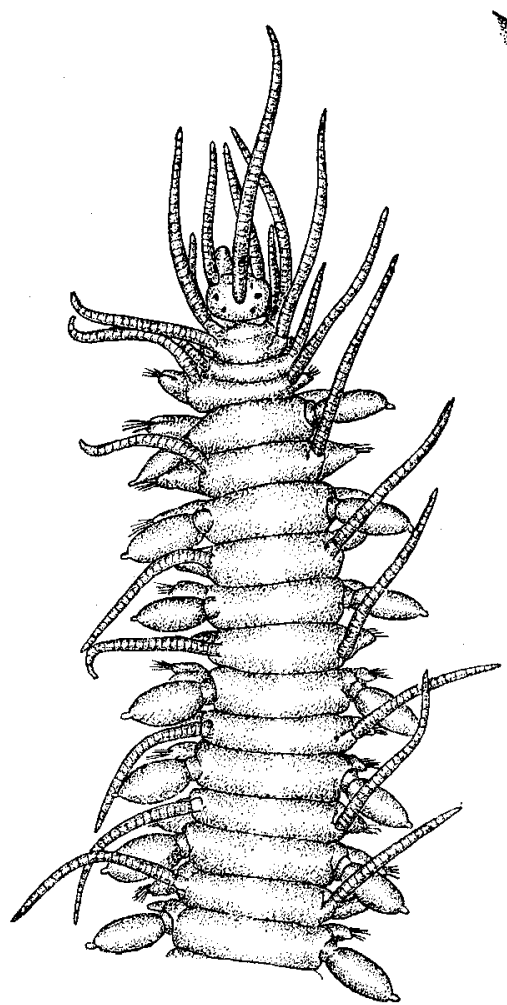

a

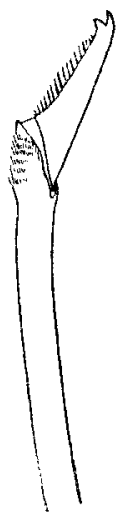

d

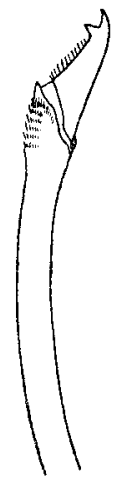

e

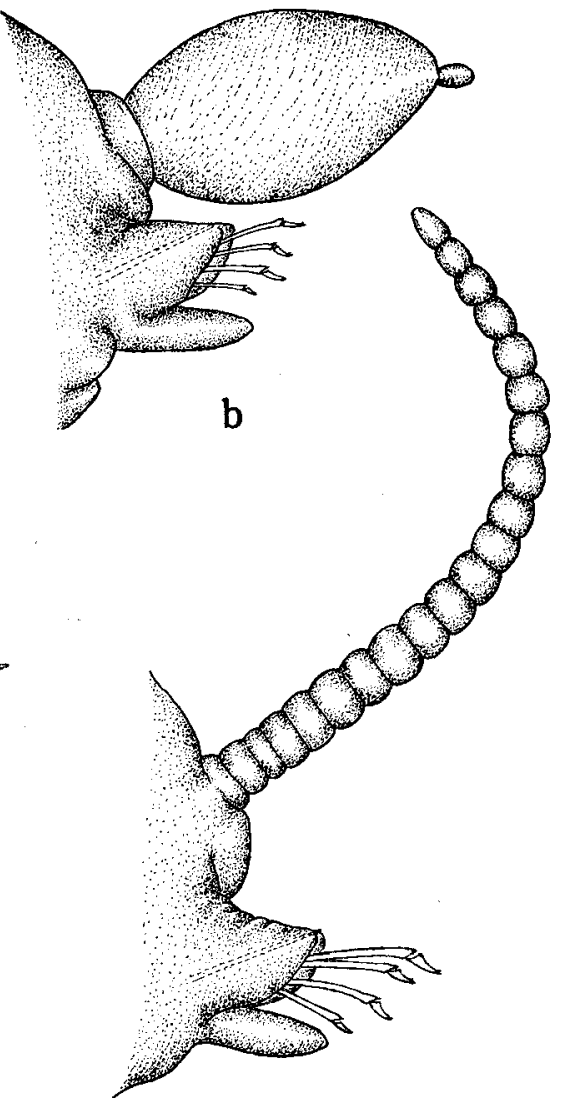

c
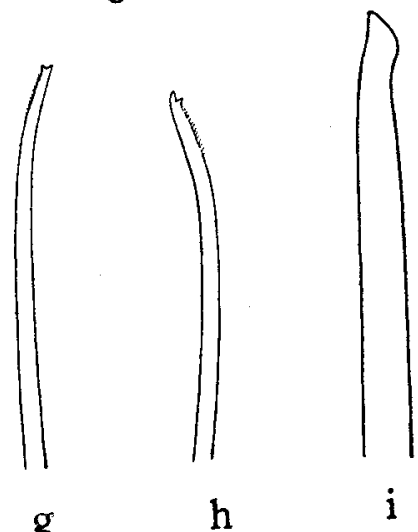

Text-fig. 50. Parasphaerosyllis setoensis n. sp. a, anterior end, in dorsal view, $\times 55$; b, parapodium with bulbous fusiform dorsal cirrus, in anterior view, $\times 190$; $\mathrm{c}$, parapodium with slender moniliform dorsal cirrus, in anterior view, $\times 190$; $\mathrm{d}$, superior compound seta from median parapodium, $\times 950$; e, median compound seta from same parapodium, $\times 950$; f, inferior compound seta from same parapodium, $\times 950 ; \mathrm{g}$, superior simple seta from posterior parapodium, $\times 950$; h, inferior simple seta from same parapodium, $\times 950$; i, aciculum, $\times 950$. 
from Shirikishinai, Hokkaido, in the features of the prostomium, antennae, palpi and setae. $P$. setoensis may be distinguished from $P$. ezoensis in that bulbous dorsal cirri are first present from setigerous segment 4, instead of 14 to 16 , and each has a terminal, single knob, instead of two articles.

Parasphaerosyllis setoensis resembles $P$. indica Monro (1937) from the south Arabian coast in having bulbous dorsal cirri with a single terminal knob. It differs in that (1) the prostomium has instead of lacks a pair of small nuchal lappets; (2) lateral antennae emerge from the anterior margin of the prostomium, not behind the anterior eyes; (3) bulbous dorsal cirri have no stalk at the base and are first present from setigerous segment 4 , instead of 16 or 23 as in a specimen from Cape Verde Islands (Rullier, 1964, p. 165).

Distribution: Southern Japan.

Langerhansia CzerniavsKY, 1881

\section{Type: Langerhansia sexoculata (EHLERS, 1864)}

The body is threadlike. The prostomium is subglobular with two pairs of reddish eyes. Three antennae, tentacular cirri and dorsal cirri are distinctly moniliform. The pharynx is distally surrounded by soft papillae and has a middorsal tooth; the anterior margin is smooth. Setae are all compound; a few superiormost ones are spinigerous with abruptly longer, narrower blades. Posterior fascicles have two additional simple setae.

\section{Key to species of Langerhansia from Japan}

1. Prostomium without eyes; setae consist of compound spinigers and bidentate and unidentate

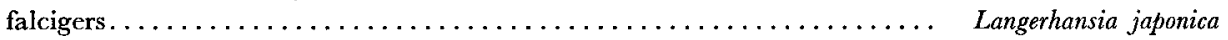

1. Prostomium with eyes; setae consist of compound spinigers and bidentate falcigers . . . . . ...2

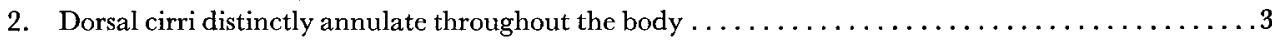

2. Dorsal cirri distinctly annulated only in anterior six segments and wrinkeld posteriorly ........

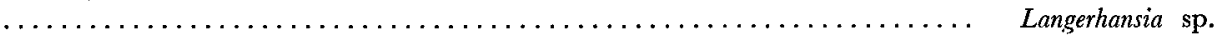

3. Spinigerous composite setae occur from the first parapodium .......... Langerhansia cornuta

3. Spinigerous composite setae occur from a more posterior parapodium ........ Langerhansia rosea

Langerhansia cornuta (RATHKE, 1843)

(Text-fig. 51, a-o)

Ehlersia (Syllis) comuta LANGERHANs, 1879, p. 537.

Syllis (Ehlersia) cornuta Fauvel, 1923, pp. 267-268, fig. 100, g-i; 1953, p. 153, fig. 79, g-i; Uschakov and Wu, 1962, p. 59; Rullier, 1964, p. 161.

Ehlersia cornuta Hartman, 1945, p. 15.

Langerhansia cornuta HARTMAN, 1959, p. 210.

Collection: Off Shirikishinai, in $140 \mathrm{~m}$; off Hakodate, in $20 \mathrm{~m}$; Uraga Strait, in 20 to $100 \mathrm{~m}$; Ariake Sea, in $10 \mathrm{~m}$; Seto; Tamano, in intertidal zone. 
Description: The largest specimen measures $16 \mathrm{~mm}$ long and $0.7 \mathrm{~mm}$ wide including parapodia; it consists of 108 setigerous segments. The body is yellowish white and has no color markings. The prostomium is broader than long, with rounded anterior margin. There are three pairs of reddish eyes: one pair is frontal and two pairs are in trapezoidal arrangement (fig. a). A median antenna arises midway between the posterior eyes; it is about 4 times as long as the prostomium and has 24 annulations. Lateral antennae emerge from anterior part of the prostomium; each is about half as long as the median antenna and has 11 to 12 annulations. The palpi are about 1.5 times as long as the prostomium; their basal one-third is fused. The pharynx terminates in 10 soft papillae and has a subdistal middorsal tooth. The proventriculus extends from setigerous segment 10 to 13 . The dorsal side of the tentacular segment is about half as long as the next segment. The dorsal tentacular cirri are slightly longer than the lateral antennae; each has 15 to 16 annulations, and the ventral cirri are about half as long as the dorsal ones. The first dorsal cirri are as long as the median antenna and each has 25 to 27 annulations (fig. b). The second and third cirri are short and the fourth ones are long. In more posterior regions the dorsal cirri alternate in length; in median parapodia they have 20 and $13 \mathrm{annu}-$ lations, and short cirri are as long as the body is wide (figs. c, d). All cirri are slender and distinctly articulated. Parapodia are short and conical; each has a fascicle of two kinds of compound setae; one or two superiormost setae have long, slender and distally tapered appendages with serrations along the cutting margin (figs. a, c); the remaining 5 to 9 setae have short bidentate appendages. The first parapodium has two long setal appendages (=spiniger) (fig. e) and their lengths are about 5 times as long as the inferior short appendage (figs. $f, g$ ). In median parapodia the appendage of the superior seta is much longer or about 7 times as long as the inferior one (fig. h). Appendages of other setae have a large secondary tooth and long, coarse serrations along the cutting margin (figs. i, j). On more posterior parapodia the superior appendages become gradually shorter to about twice as long as the inferior (fig. $\mathrm{k}$ ) ones, and remaining setae have short appendages with minute serrations along the cutting margin (fig. 1). There are two additional simple setae in superior and inferior positions of the fascicles; the superior one terminates distally in a blunt tip (fig. $\mathrm{m}$ ), and the inferior one is distally bifid (fig. $\mathbf{n}$ ). Ventral cirri are digitate and extend to the tip of the setigerous lobe. Acicula number two to one in a fascicle; each has a blunt tip (fig. o).

Syllis cornuta WESENBERG-Lund (1947, p. 6, fig. 2b) from Greenland is questionable because spinigers in superior-most position of the fascicle are not described and are not shown.

Typosyllis alternata (Moore, 1908) has been referred to this species by PetTIBone (1948). T. alternata identified by BERKELEY from western Canada was compared with two specimens of $L$. cornuta from France referenced by Fauvel. The two species are separable in their composite setae; $T$. alternata has superior setae with appendages 


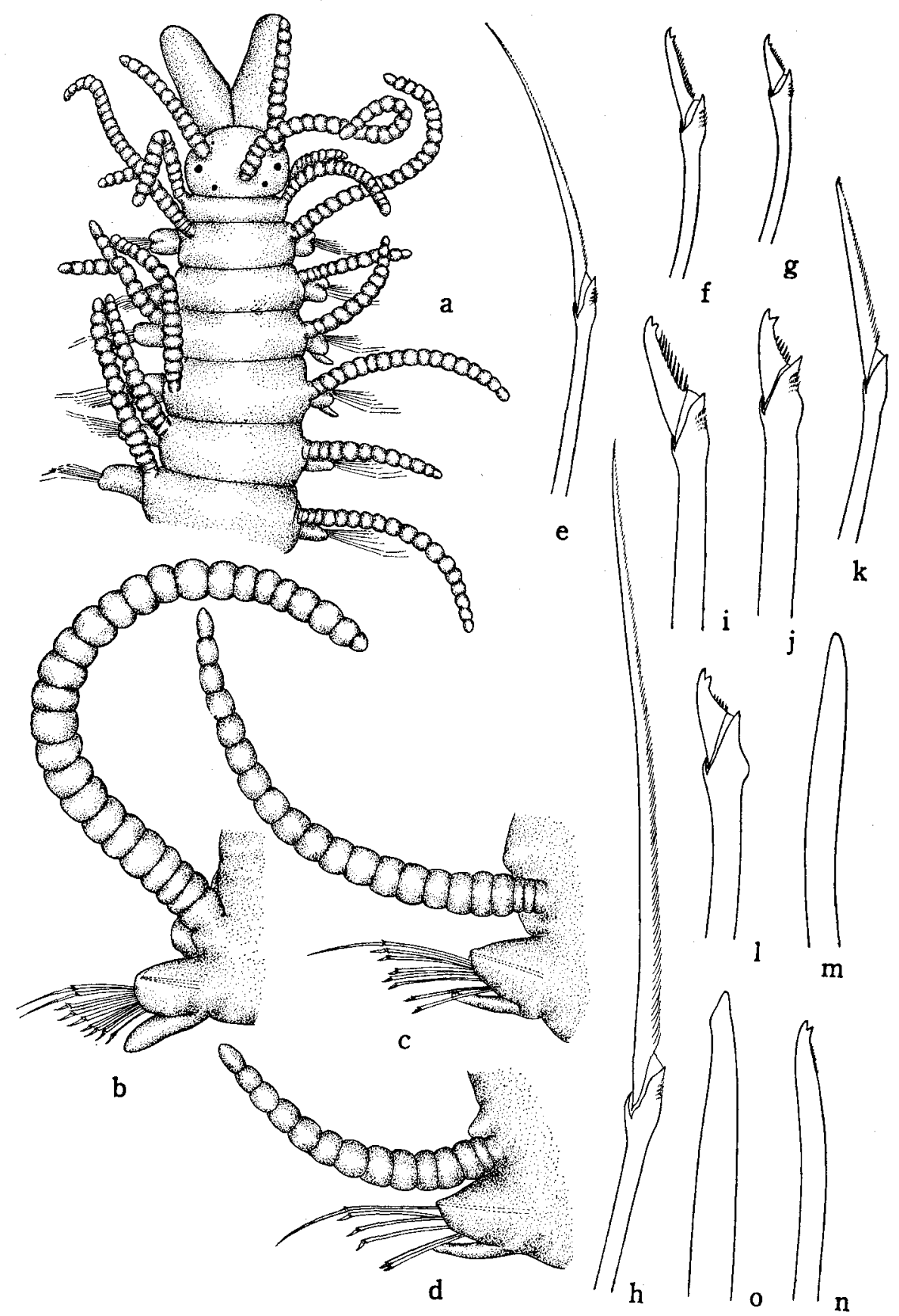

Text-fig. 51. Langerhansia cornuta (RAthke). a, anterior end, in dorsal view, $\times 70$; b, lst parapodium, $\times 170$; c, median parapodium with long dorsal cirrus, in anterior view, $\times 100$; $\mathrm{d}$, median parapodium with short dorsal cirrus, in same view, $\times 100$; e, spiniger 
about twice as long as the inferior ones and similar to those inferior; they are not distally tapered as in L. cornuta (RATHKE).

The genus and species are new to Japan.

Distribution: Norway; Mediterranean Sea; North Carolina; Indian Ocean; Indo-China; Yellow Sea; Japan.

\section{Langerhansia rosea (LANGERHANS, 1879)}

(Text-fig. 52, a-m)

Ehlersia (Syllis) rosea LANGeRHAns, 1879, p. 538, fig. 5.

Collection: Uraga Strait, in $20 \mathrm{~m}$; Sugashima; Mukaishima; Usa; Noto-ogi, in intertidal zone.

Description: The largest specimen measures $17 \mathrm{~mm}$ long and $0.4 \mathrm{~mm}$ wide including parapodia; it consists of 120 setigerous segments. The body is threadlike, yellow, and has no color markings. The prostomium is subglobular, and wider than long (fig. a). Two pairs of reddish eyes are in trapezoidal arrangement and the anterior pair is the larger. A median antenna arises from the center of the prostomium; it is about 4 times as long as the prostomium, and has 20 annulations. Lateral antennae arise from anterior margin of the prostomium and each has 14 to 15 annulations. Palpi are subtriangular and slightly longer than the prostomium; they are fused at the bases. The pharynx is distally surrounded by 10 soft papillae and has a subdistal, middorsal tooth. The proventriculus extends through setigerous segments 14-16. The dorsum of the tentacular segment is about as long as the first setigerous segment. The dorsal tentacular cirri are about two-thirds as long as the median antenna, with 14 to 17 annulations, and ventral cirri are about half as long as the dorsal one. The first dorsal cirri are about twice as long as the lateral antennae, with 23 to 27 annulations. The second and third dorsal cirri are short and the fouth ones are again long. Thereafter dorsal cirri alternate long and short; in median segments each has 20 or 15 annulations; the short ones are as long as the body is wide (figs. b, c). A normal parapodium is conical and has a fascicle of composite setae. On the first 14 to 20 parapodia compound setae are of one kind, with short appendages having a distinct secondary tooth, but superior appendages are slightly longer than the inferior ones (figs. d, c); the cutting margin has long serrations. Superior setac in the following fascicles have a long, slender appendage, with serrations along the cutting margin (=spiniger); its length is 5 to 6 times as long as those in inferior

from 1st parapodium, $\times 840$; $\mathrm{f}$, median compound seta with short appendage from same parapodium, $\times 840$; $\mathrm{g}$, inferior compound seta from same parapodium, $\times 840$; $\mathrm{h}$, spiniger from median parapodium, $\times 840 ; \mathrm{i}$, median compound seta from same parapodium, $\times 840 ; \mathrm{j}$, inferior compound seta from same parapodium, $\times 840 ; \mathrm{k}$, spiniger from posterior parapodium, $\times 840$; 1 , inferior compound seta from same parapodium, $\times 840$; $\mathrm{m}$, superior simple seta from same parapodium, $\times 840 ; \mathrm{n}$, inferior simple seta from same parapodium, $\times 840$; o, aciculum from median parapodium, $\times 840$. 


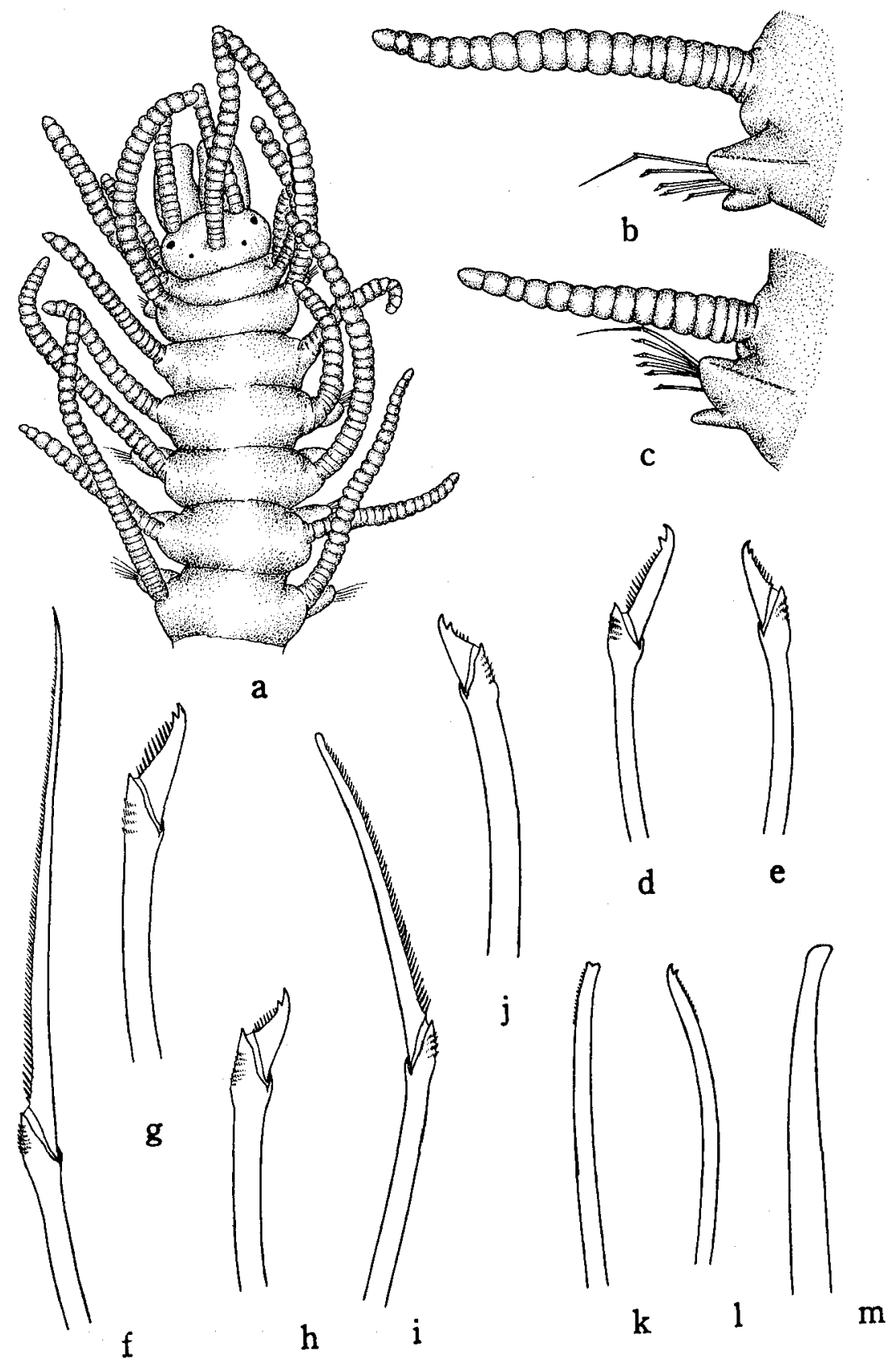

Text-fig. 52. Langerhansia rosea (LANGerhans). a, anterior end, in dorsal view, $\times 80$; $b$, median parapodium with long dorsal cirrus, in anterior view, $\times 95$; $c$, median parapodium with short dorsal cirrus, in same view, $\times 95$; d, superior compound seta from 1st parapodium, $\times 950$; e, inferior compound seta from same parapodium, $\times 950$; f, superior spiniger from median parapodium, $\times 950 ; \mathrm{g}$, median compound seta from same parapodium, $\times 950 ; \mathrm{h}$, inferior compound seta from same parapodium, $\times 950$; i, superior spiniger from posterior parapodium, $\times 950 ; \mathrm{j}$, inferior compound seta from same parapodium, $\times 950 ; \mathrm{k}$, superior simple seta from same parapodium, $\times 950 ; 1$, inferior simple seta from same parapodium, $\times 950 ; \mathrm{m}$, aciculum from median parapodium, $\times 950$. 
position (fig. f). The remaining 4 to 6 setae have short bidentate appendages with long serrations along the cutting margin (figs. g, h). Posterior parapodia have setal fascicles similar to those in median parapodia, but a superior appendage terminates distally in a slight knob (fig. i). Other setae are like those of the more anterior region (fig. j). There are two additional simple setae, one in superior, and one in inferior position. The first is just above the aciculum and has a slightly bifid, truncate tip, and fine serrations along one side of the shaft (fig. $\mathrm{k}$ ). The inferior one is distinctly bifid and has minute serrations on one side (fig. 1). Acicula number one to two in a parapodium; each is bluntly rounded (fig. $\mathrm{m}$ ). The pygidium has two anal cirri.

The species is new to Japan.

Distribution: Madeira; southern Japan.

\section{Langerhansia japonica $\mathrm{n}$. sp.}

(Text-fig. 53, a-i)

\section{Collection: Uraga Strait, in $20 \mathrm{~m}$.}

Description: The larger of two specimens, lacking posterior parts measures $16 \mathrm{~mm}$ long and $0.8 \mathrm{~mm}$ wide including parapodia; it consists of 91 setigerous segments. The body is yellowish white and has no color markings. The prostomium is subpentagonal and wider than long (fig. a). Eyes are not visible. A median antenna with 33 annulations arises from the center of the prostomium and is about 3.5 times as long as the prostomium. Lateral antennae emerge from the anterior margin of the prostomium and each is about half as long as the median one. Palpi are subtriangular and fused to each other in their basal one-third. The pharynx terminates in 10 soft papillae and has a subdistal, middorsal tooth in its inner wall (fig. b). The proventriculus extends from setigerous segment 13 to 17 . The tentacular segment is distinct on the dorsum and about half as long as the next segment. The dorsal tentacular cirri are more than two-thirds as long as the median antenna; ventral ones are about two-thirds as long as the dorsal ones. Dorsal cirri are slender and distinctly articulated; they alternate long and short. Median parapodia have short cirri each with about 40 annulations and slightly longer than the body is wide; long cirri each with about 50 articles are about twice as long as the short ones (figs. c, d); each cirrus has a cylindrical cirrophore. A normal parapodium is conical and has setae consisting of one simple and three kinds of compound setae. A simple acicular seta appears first from the 32th parapodium, above the two embedded acicula; it ends in a pointed tip (fig. e). Compound setae are of three kinds: (1) 1 to 2 setae with much longer, slenderer, distally pointed appendage (=spiniger), having minute serrations along the cutting margin (fig. f); (2) 4 median setae with short appendages and falcate tips, each with a long, slender secondary tooth which nearly reaches the falcate tip, and with coarse serrations along the cutting margin (fig. g), and (3) 3 inferior setae with short, unidentate appendages with smooth cutting edge (fig. h). Acicula number 


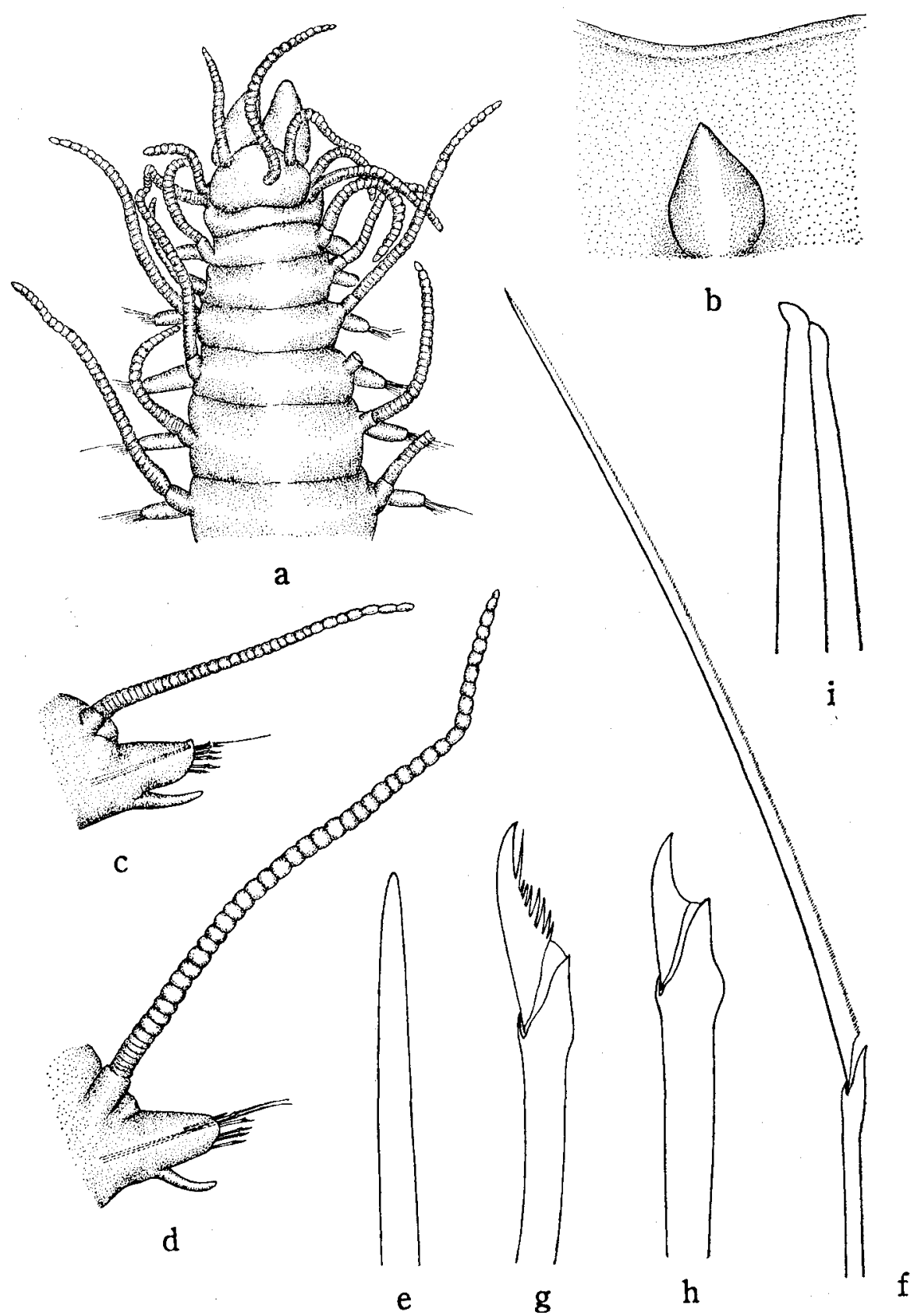

Text-fig. 53. Langerhansia japonica n. sp. a, anterior end, in dorsal view, $\Varangle 55$; b, a part of distal part of pharynx opened by dissection showing a middorsal tooth, $\times 265$; c, median parapodium with short dorsal cirrus, $\times 80$; $d$, median parapodium with long dorsal cirrus, $\times 80$; e, superior simple acicular seta above inner acicula from median parapodium, $\times 950 ; \mathrm{f}$, superior spiniger from same parapodium, $\times 800$; , median compound seta with a long secondary tooth from same parapodium, $\times 950 ; \mathrm{h}$, inferior unidentate compound seta from same parapodium, $\times 950 ; i$, acicula from same parapodium, $\times 950$. 
2 to 3 in a series; each terminates in a bent tip (fig. i). Ventral cirri are digitate and do not extend distally beyond the parapodial lobes.

Langerhansia japonica is characterized in having a simple aciculum and three kinds of compound setae in a normal fascicle. It resembles $L$. anops (EHLERs, 1897) from the Strait of Magellan, in the features of body and dorsal cirri; it differs in that the setae include a simple acicular spine above the acicula, and composite setae are of three instead of two kinds.

Distribution: Central Japan.

\section{Langerhansia sp.}

(Text-fig. 54, a-j)

Collection: Seto, in intertidal zone.

Description: Two anterior fragments were examined. The larger one measures $7 \mathrm{~mm}$ long and $0.6 \mathrm{~mm}$ wide for 69 setigerous segments. The body is yellowish white and has no color markings; each segment has one ciliary band across the dorsum. The prostomium is broader than long, has two pairs of reddish eyes in trapezoidal arrangement with the anterior larger pair crescentic (fig. a). A median antenna has 25 annulations and is about four times as long as the prostomium; it is inserted at the center of the prostomium. Each of the lateral antennae is about half as long as the median one; they are inserted at the anterior margin. Palpi are triangular and fused at their bases; they are longer than the prostomium. The pharynx terminates in 8 soft papillae; a large subterminal middorsal tooth is present. The proventriculus extends through setigerous segments 6 to 9 . The dorsal tentacular cirri are about as long as the lateral antennae; the ventral cirri are about half as long as the dorsal ones. The first dorsal cirri are about as long as the median antenna; each has 23 annulations. The fourth and sixth dorsal cirri are long and similar to the first ones (fig. b). The second, third and fifth cirri are short and each has 10 to 14 annulations. The first six dorsal cirri are distinctly annulated. Each of the seventh dorsal cirri has 7 annulations with each annulus longer than those in front (fig. c). On more posterior segments the dorsal cirri are slender; each is cirriform and has 2 to 5 long annuli (figs. d, e). The cirri alternate long and short and the long ones are about as long as the body is wide. A normal parapodium is distally obliquely bluntly conical; the setae emerge from between two lobes. Those in the anterior ten parapodia have bidentate compound setae; the appendages have coarse serrations along the cutting margin; appendages of three superior setae are longer than the others (figs. $f, g$ ). On more posterior fascicles the appendages of two or three superior setae are much longer and distally tapered, with minute serrations along cutting edge (fig. h). The appendages of other setae are short, or about half as long as the inferior setae in anterior parapodia; a subdistal secondary tooth is larger than 


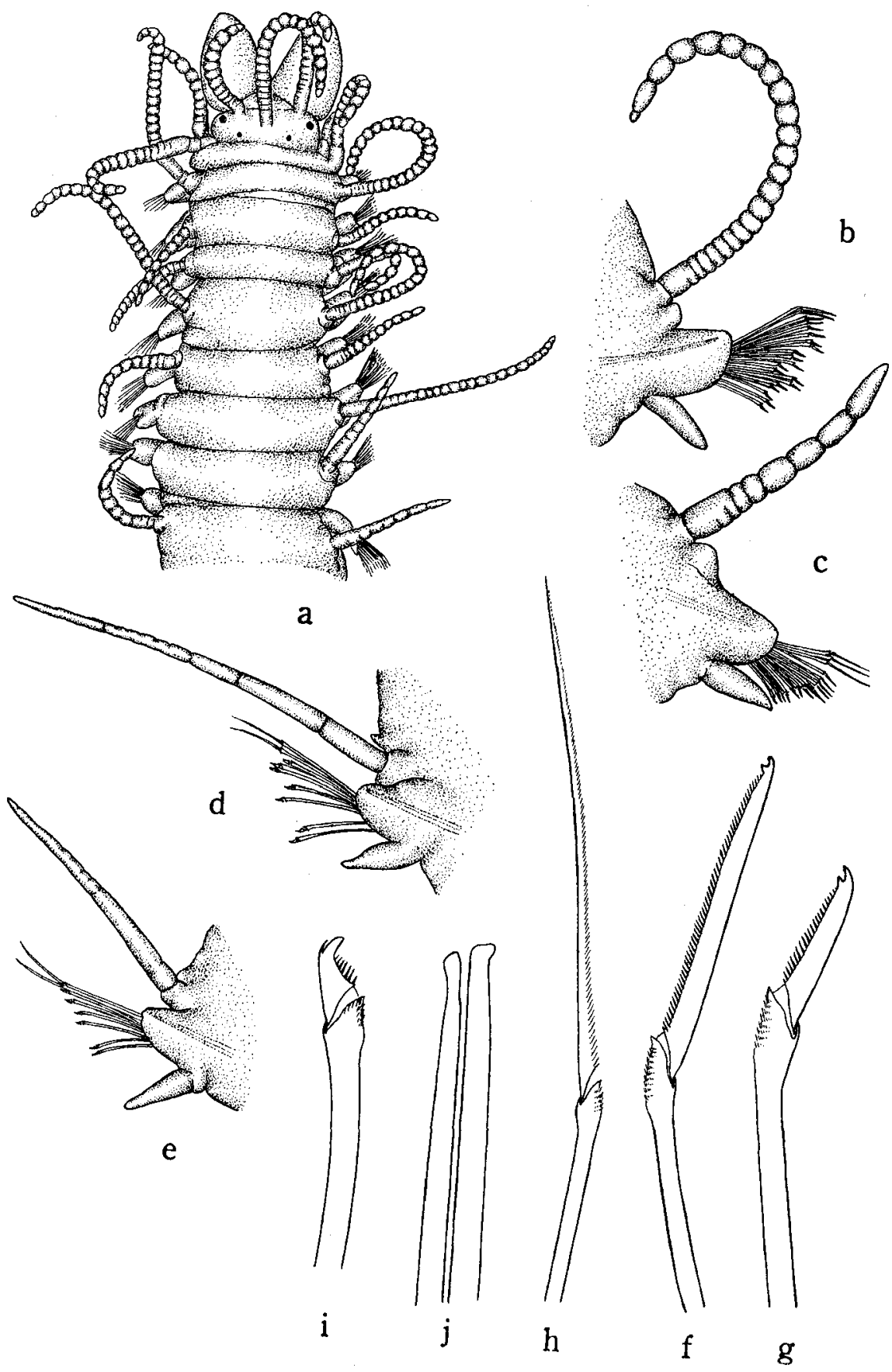

Text-fig. 54. Langerhansia sp. a, anterior end, in dorsal view, $\times 65 ; b, 4$ th parapodium, in posterior view, $\times 120 ; \mathrm{c}$, 7th parapodium, in same view, $\times 120 ; \mathrm{d}, 27$ th parapodium, in same view, $\times 120$; e, 28th parapodium, in same view, $\times 120 ; \mathrm{f}$, superior compound seta from 4th parapodium, $\times 950 ; \mathrm{g}$, median or inferior seta from same parapodium, $\times 950$; $h$, superior spiniger from $27 \mathrm{th}$ parapodium, $\times 950$; $i$, median or inferior seta from same parapodium, $\times 950 ; j$, acicula from same parapodium, $\times 950$. 
the distal tooth, and the cutting margin has coarse serrations (fig. i). The posterior parapodia and pygidium are not known. Acicula number two to four in a parapodium; each has a blunt tip (fig. j).

Most species of Langerhansia have distinctly annulated dorsal cirri throughout the body and few composite spinigers in each setal fascicle. In the present specimens the first six dorsal cirri are distinctly annulated, but the following cirri have indistinct annulations much like those of Pionosyllis. They are referred to Langerhansia, because composite spinigerous setae occur in some parapodia.

A specific name is not given because the materials are anterior fragments only.

Distribution: Southern Japan.

\section{Typosyllis LANGERHANS, 1879}

\section{Type: Typosyllis krohnii (EHLERS, 1864)}

The body is slender and subcylindrical. The prostomium is subglobular and has two pairs of eyes. Three antennae, tentacular cirri and dorsal cirri are distinctly articulated; they range from long and slender to short and fusiform or distally inflated. Palpi are broadly triangular and fused at their bases. The pharynx is surrounded by 10 soft papillae; the anterior margin of the inner wall is smooth and has a subdistal, middorsal tooth. Parapodia are conical with fascicles of uni- or bidentate compound setae; one or two additional simple setae occur in the posterior parapodia. Ventral cirri are digitate. The pygidium has two long anal cirri.

Key to species of Typosyllis from Japan

1. Dorsal cirri in median region with fewer than 20 articles $\ldots \ldots \ldots \ldots \ldots \ldots \ldots \ldots \ldots \ldots \ldots$

1. Dorsal cirri in median region with more than 20 articles $\ldots \ldots \ldots \ldots \ldots \ldots \ldots \ldots \ldots \ldots \ldots$

2. Median dorsal cirri slender, cirriform; body greenish; each segment triannulate ............. $\ldots \ldots \ldots \ldots \ldots \ldots \ldots \ldots \ldots \ldots \ldots \ldots \ldots \ldots \ldots \ldots \ldots \ldots \ldots \ldots \ldots \ldots \ldots \ldots \ldots \ldots$ Typosyllis nipponica

2. Median dorsal cirri more or less fusiform; body pinkish, with or without color pattern; each segment

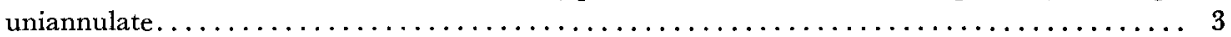

3. Compound seta with appendage distally entire $\ldots \ldots \ldots \ldots \ldots \ldots \ldots \ldots \ldots$ Typosyllis okadai

3. Compound seta with appendage distally bifid $\ldots \ldots \ldots \ldots \ldots \ldots \ldots \ldots \ldots \ldots \ldots \ldots \ldots \ldots$

4. Dorsum with broad pigment band on every one to three segments; compound seta all of one kind $\ldots \ldots \ldots \ldots \ldots \ldots \ldots \ldots \ldots \ldots \ldots \ldots \ldots \ldots \ldots \ldots \ldots \ldots \ldots \ldots \ldots \ldots \ldots \ldots \ldots \ldots \ldots$ Typosylis hyalina

4. Dorsum with two parallel, or broken transverse lines on each segment; median composite setae with minute accessory tooth $\ldots \ldots \ldots \ldots \ldots \ldots \ldots \ldots \ldots \ldots \ldots \ldots$ Typosyllis aciculata orientalis

4. Dorsum without color pattern; median composite setae with distinct secondary tooth ..........

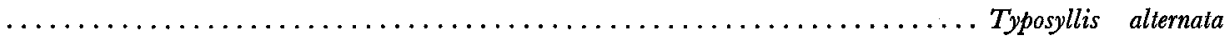

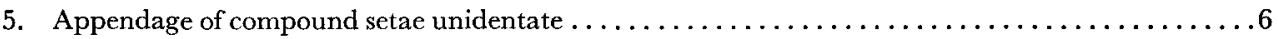

5. Appendage of compound setae either unidentate or bidentate; dorsal cirri with regulary arranged pigmented annulations $\ldots \ldots \ldots \ldots \ldots \ldots \ldots \ldots \ldots \ldots \ldots \ldots \ldots \ldots \ldots \ldots \ldots \ldots$ Typosylis maculata

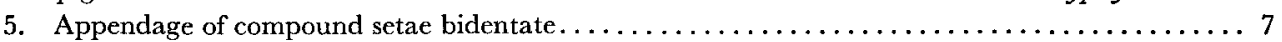

6. Dorsum with white oval spot on each segment; each posterior parapodium with two simple setae $\ldots \ldots \ldots \ldots \ldots \ldots \ldots \ldots \ldots \ldots \ldots \ldots \ldots \ldots \ldots \ldots \ldots \ldots \ldots \ldots \ldots \ldots \ldots \ldots$ Typosylis adamanteus kurilensis

6. Dorsum without color pattern; each posterior parapodium with one simple superior seta .......

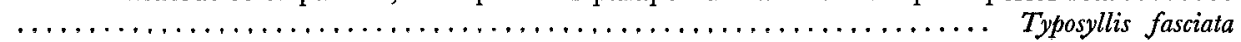


7. All compound setae with minute accessory tooth $\ldots \ldots \ldots \ldots \ldots \ldots$ Typosyllis ehlersioides

7. All compound setae with large, distinct, secondary tooth $\ldots \ldots \ldots \ldots \ldots \ldots \ldots \ldots \ldots \ldots$

8. Anterior dorsal cirri alternate thick and slender $\ldots \ldots \ldots \ldots \ldots \ldots \ldots \ldots \ldots \ldots \ldots \ldots \ldots$

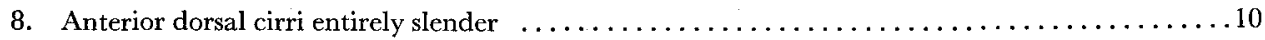

9. Dorsum with white oval spot on each segment; composite setae of median parapodia with uniform appendages $\ldots \ldots \ldots \ldots \ldots \ldots \ldots \ldots \ldots \ldots \ldots \ldots \ldots \ldots \ldots \ldots \ldots \ldots \ldots \ldots \ldots$ Typosyllis lunaris

9. Dorsum without color pattern; composite setae of median parapodia with long and short appendages

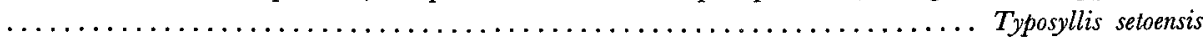

10. First two setigerous segments darkly pigmented................ Typosyllis monilata

10. First two setigerous segments not darkly pigmented $\ldots \ldots \ldots \ldots \ldots \ldots \ldots \ldots \ldots \ldots \ldots \ldots$

11. With long and short appendaged composite setae in all parapodia; without color pattern on dorsum

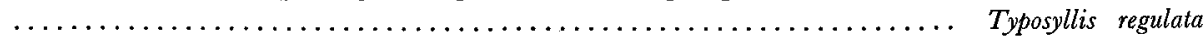

11. Appendages of composite setae differ in length in anterior and median parapodia; with or without

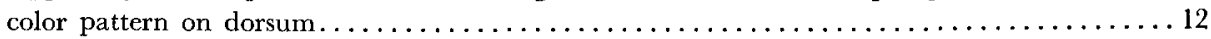

12. Dorsum with irregular, purple transverse bands on each segment; proventriculus extends through

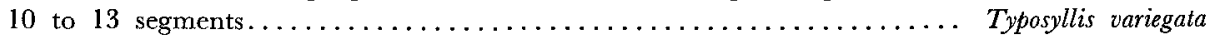

12. Dorsum brownish purple, no color markings; proventriculus extends through 5 to 6 segments

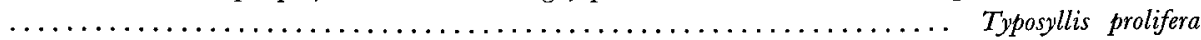

\section{Typosyllis nipponica $\mathrm{n}$. sp.}

(Text-fig. 55, a-o)

Syllis inflata FAUvel, 1934, pp. 309-310.

Collection: Funadomari, in Rebun Island; Shukutsu; Matsumae; Fukushima; Shirikishinai; Akkeshi; Saroma Lake; Asamushi; Onagawa; Misaki; Sugashima; Seto; Tamano; Mukaishima; Usa; Noto-ogi, in intertidal zone.

Description: The largest specimen measures $60 \mathrm{~mm}$ long and $1.2 \mathrm{~mm}$ wide including parapodia; it consists of 167 setigerous segments. The body is green and dorsal cirri are yellowish green. The dorsum of the fifth setigerous segment is dark because of a band of black pigments in the inner wall of the pharynx (fig. a). All segments except a few anterior ones are triannulated, most distinct in median region (fig. b). The prostomium is subglobular and wider than long; there are two pairs of small eyes in trapezoidal arrangement. A pair of nuchal lappets are present along the posterior margin of the prostomium. The median antenna arises from the center of the prostomium and is about four times as long as the prostomium; it has 14 annulations. Lateral antennae are inserted at the anterior margin of the prostomium and each has 8 to 10 annulations. Palpi are broadly triangular and fused at their bases; they are about as long as the prostomium. The pharynx is thick and terminates in

Text-fig. 55. Typosyllis nipponica $\mathrm{n}$. sp. a, anterior end, in dorsal view, $\times 25$; b, four segments in median region showing triannulate segments, in dorsal view, $\times 25$; , distal part of pharynx opened by dissection, $\times 35$; $d$, median parapodium with short dorsal cirrus, in anterior view, $\times 57$; e, median parapodium with long dorsal cirrus, in same view, $\times 57$; $\mathrm{f}$, superior compound seta from anterior parapodium, $\times 720 ; \mathbf{g}$, inferior compound seta from same parapodium, $\times 720 ; \mathrm{h}$, superior compound seta from median parapodium, $\times 720$; , inferior compound seta from same parapodium, $\times 720 ; j$, posterior parapodium, 


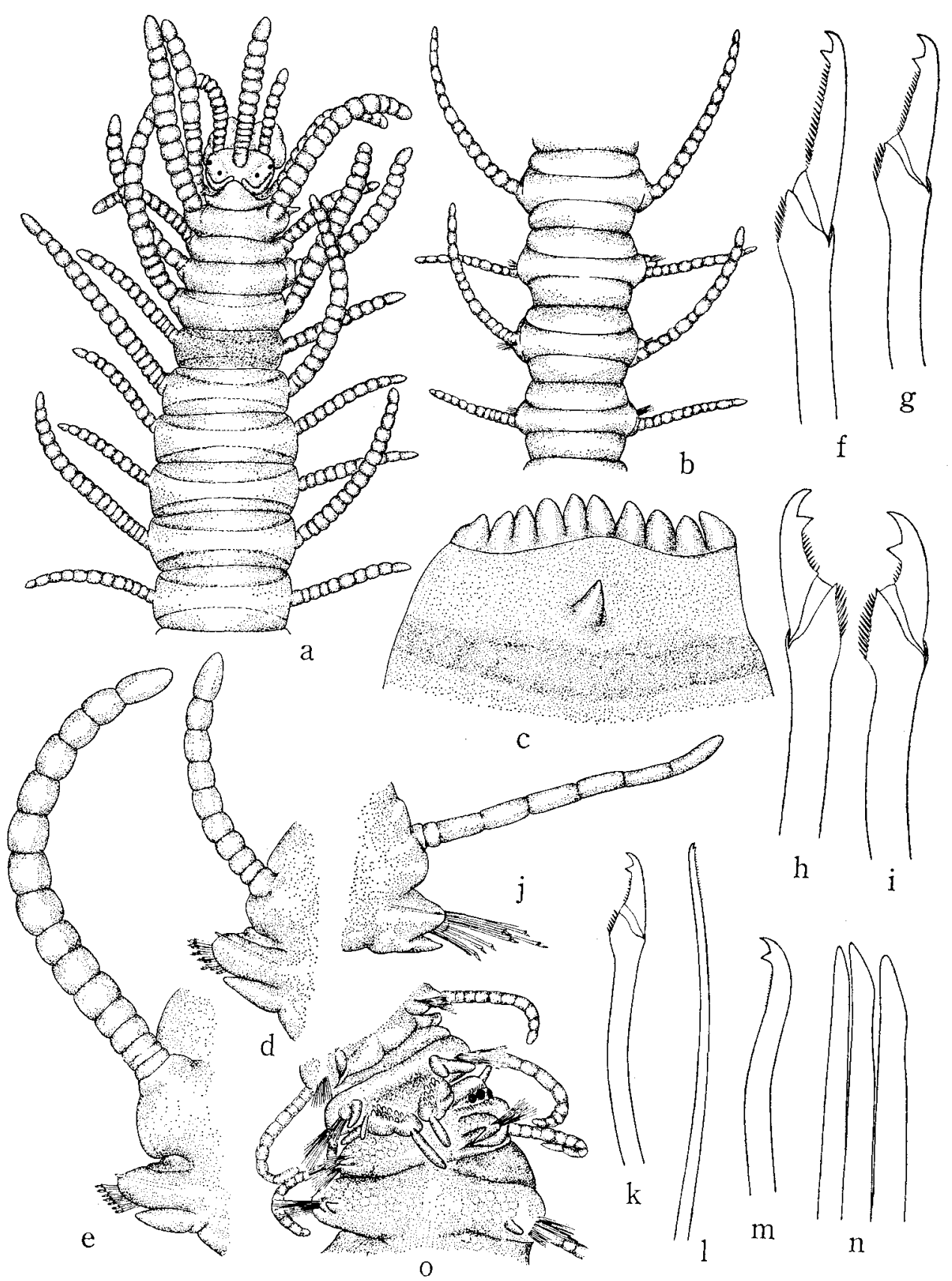

$\times 57 ; \mathrm{k}$, compound seta from posterior parapodium, $\times 720 ; 1$, superior simple seta from same parapodium, $\times 720 ; \mathrm{m}$, inferior simple seta from same parapodium, $\times 720$; $\mathrm{n}$, acicula from anterior parapodium, $\times 720 ; \mathrm{o}$, a part of body in ventral view, showing two newly formed posterior ends, $\times 22$. 
10 soft papillae; it has a large, subterminal, middorsal tooth. The anterior margin of the inner wall is smooth and pale except for a transverse pigmented band behind the middorsal tooth (fig. a). The proventriculus extends through setigerous segments 5 to 9 or 6 to 10 . The dorsal tentacular cirri of the first segment are slightly longer than the median antenna; the ventral cirri are about half as long as the dorsal ones. The first dorsal cirri are about as long as the dorsal tentacular cirri and each has 13 to 14 annulations. The second, fifth, seventh and eighth dorsal cirri are short and each has 9 to 12 annulations; the third, fourth, sixth and ninth cirri are long, each with 14 to 17 rings. Thereafter, cirri alternate short and long, having 9 and 15 annulations in the middle region of the body; the short one is about as long as the body is wide (figs. d, e). A normal parapodium is bluntly conical; it has a fascicle of bidentate composite setae between two lobes. The setal appendages in anterior parapodia are long; each has a large, subtriangular secondary tooth and serrations along the cutting margin. The appendage of superior setae (fig. b) is longer than that of inferior ones (fig. g); the distal part of the shaft has coarse serrations. Setae in median parapodia are distally falcate and have a conspicuous secondary tooth, which in inferior setae, is present about midway between the tip and base of the appendage (figs. h, i). The serrations of the shaft are longer than those of anterior ones. Dorsal cirri of posterior parapodia are slender and their annulations are cylindrical (fig. $\mathbf{j}$ ). Posterior compound setae are slenderer but similar to the superior setae in median parapodia (fig. k). In addition, there are two simple setae, one in superior and one in inferior position; the first is just above the aciculum and distally bifid, with fine serrations along one side of the shaft (fig. 1), and the second is thicker and has a distinct, subdistal secondary tooth (fig. m). Acicula number 3 in anterior parapodia (fig. $\mathrm{n}$ ) and decrease gradually in number to one in posterior segments.

One specimen has a pair of newly formed, caudal regenerations on the ventral side between the 71 th and 72 th setigerous segment; they consist of about 7 segments and an anal cirrus is already elongated (fig. o).

Syllis (Typosyllis) corruscans Haswell (1920) from Australia is $14 \mathrm{~cm}$ long for 150 to 200 segments; the dorsum is usually dark green, sometimes dark brown; each segment has two or three transverse rows of corrugations and setae have bidentate long appendages. $S$. (T.) corruscans differs from $T$. nipponica in that dorsal cirri are light red or orange, and antennae and dorsal cirri are not distinctly articulated.

Two specimens of Syllis inflata Fauvel (1934) from Misaki and Seto were reexamined. Their characteristics correspond with these of the present species.

Distribution: Northern to southern Japan.

Typosyllis okadai (FAUvEL, 1934)

(Text-fig. 56, a-1)

Syllis okadai FAUVEL, 1934, pp. 307-309, text-figs. 1, 2. 
Syllis (Typosyllis) okadai Fauves, 1953, pp. 152-153, fig. 76.

Typosyllis okadai Imajima and Hartman, 1964, p. 137.

Collection: Seto, in intertidal zone.

Description: The largest specimen measures $24 \mathrm{~mm}$ long and $1.3 \mathrm{~mm}$ wide including parapodia; it consists of 108 setigerous segments. The prostomium, the palpi (except their distal ends) and the first two, and the seventh to ninth setigerous segments are dark chocolate in color (fig. a). The tentacular segment and the third to sixth, and the tenth and eleventh, setigerous segments are white, and the following segments are brown, with two median and two lateral longitudinal rows of clear spots on the dorsum. The prostomium is broader than long and has two pairs of reddish eyes in trapezoidal arrangement. Palpi are subtriangular and about as long as the prostomium; they are fused at the bases. A median antenna arises from the center of the prostomium and has 20 annulations. Lateral antennae arise from the anterior margin of the prostomium and each has 13 to 14 annulations; they are about twothirds as long as the median antenna. The pharynx is distally surrounded by 10 soft papillae and has a middorsal tooth in the inner wall (fig. b). The proventriculus extends from setigerous segment 9 to 14 . The tentacular segment is about half as long as the second segment. The dorsal tentacular cirri are slightly longer than the lateral antennae and the ventral one is about two-thirds as long as the dorsal one. The first dorsal cirri are longer than the following cirri and each has 21 to 23 annulations. Dorsal cirri alternate in length; the long ones have 13 annulations and are about half to two-thirds as long as the body is wide (fig. c). A normal parapodium is bluntly conical; it has a fascicle of compound falcigers. Anterior parapodia have setae of two kinds: superior appendages are longer than inferior ones and have an accessory tooth; inferior appendages are unidentate; all have serrations along the cutting margins (figs. d, e). Setae in median segments are thicker than those in anterior segments, and have a short, falcate unidentate appendage with minute serrations along the cutting margin (figs. $f, g$ ). The shafts of the setae are subdistally thickened. Posterior parapodia are provided with compound setae similar to those in median parapodia (fig. h) or with slenderer appendage (fig. i). These fascicles also contain two simple setae, one in superior, the other in inferior position. The superior seta has a large subdistal secondary tooth (fig. $\mathrm{j}$ ) and the inferior one has an acutely curved tip (fig. k); both have minute serrations along one side. Acicula number 5 in anterior parapodia and decrease gradually to one in posterior segments; each is distally pointed (fig. 1).

Typosyllis okadai Fauvel (1934) was first recorded from Seto. A part of the original description is emended: (1) the superior setae of anterior parapodia have a subdistal secondary tooth, instead of being unidentate, and (2) posterior parapodia have two simple setae instead of only one in superior and inferior positions.

Distribution: Japan; Gulf of Siam; Andaman Islands. 

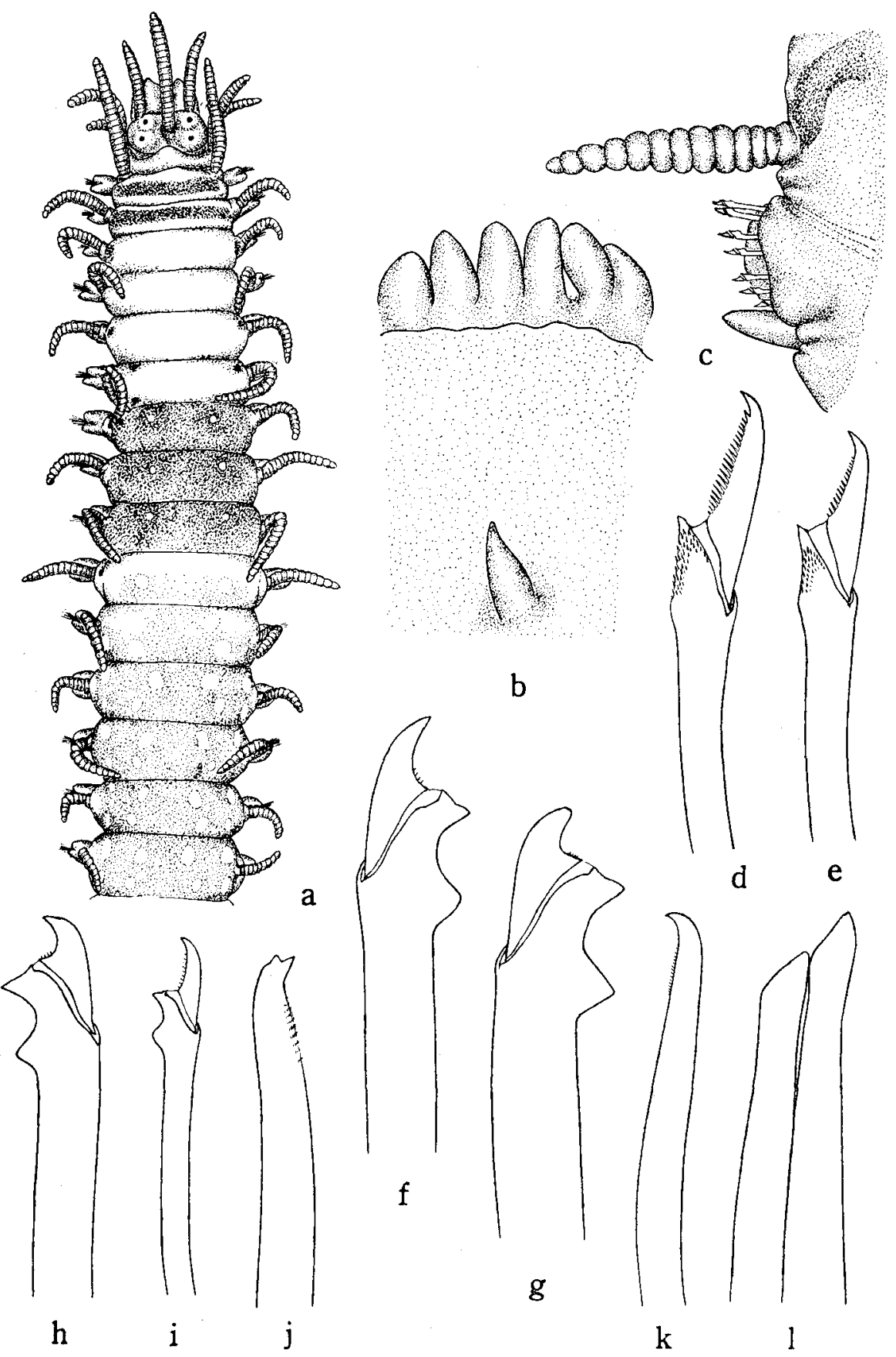

Text-fig. 56. Typosyllis okadai (FAuvel). a, anterior end, in dorsal view, $\times 30$; $\mathrm{b}$, a part of pharynx opened by dissection, $\times 75$; c, median parapodium, in anterior view, $\times 120$; d, superior compound seta from anterior parapodium, $\times 950$; e, inferior compound seta 


\title{
Typosyllis hyalina (GRUBE, 1863)
}

\author{
(Text-fig. 57, a-k)
}

Syllis (Typosyllis) hyalina FAUvel, 1923, pp. 262-263, fig. 98a-c; Rullier, 1964, pp. 159-160. Syllis hyalina BERKELEY and BERKELEY, 1948, p. 74, figs. 107, 108.

Collection: Shirikishinai, from holdfasts of Laminaria; Matsumae; Onagawa ; Notoogi, in intertidal zone.

Description: The largest specimen measures $16 \mathrm{~mm}$ long and $1.3 \mathrm{~mm}$ wide including parapodia; it consists of 74 setigerous segments. The entire dorsum has broad, brown bands on every one to three segments; each band extends across the segment (fig. a). The prostomium is subglobular and wider than long; there are two pairs of eyes in trapezoidal arrangement and a pair of much smaller frontal eyes is located between the bases of the lateral antennae. Palpi are subtriangular and about 1.5 times as long as the prostomium; they are fused at their bases. A median antenna arises from the center of the prostomium and is about twice as long as the prostomium; it has 13 to 14 annulations. Lateral antennae arise from anterior part of the prostomium and each has 10 to 12 annulations. The pharynx is distally surrounded by 10 soft papillae and has a subdistal middorsal tooth in its inner wall. The proventriculus extends through setigerous segments 10 to 21 . The dorsal tentacular cirri are longer than the median antenna and each has 17 to 18 annulations; the ventral cirri are about as long as the median antenna. The first dorsal cirri are long and each has 20 annulations. The second, third and fifth cirri are short, each with 11 to 14, and the fourth and sixth are long, with 16 annulations. The following two cirri are short and the ninth ones are long. Afterward, they alternate long and short and in median region they alternate short, with 11 and long with 14 annulations (figs. b, c). All cirri are distinctly annulated and basaly thickest. A normal parapodium is bluntly conical and has compound setae numbering about 10 in a bundle; all are bidentate. Setae in the anterior region have appendages subequal in length in superior and inferior positions of the fascicle (figs. d, e). These of median and posterior parapodia are thicker than anterior ones and each is similar; the serrations along the cutting margin are much smaller than those of anterior setae (figs. $f, g$ ). On posterior parapodia dorsal cirri are similar to those of the median region. Two simple setae are present in superior- and inferior-most parts of the fascicles (fig. $\mathbf{h}$ ); each is subequal in thickness; the superior one has a subdistal accessory tooth with minute serrations (fig. i), and the inferior seta has a small, subdistal secondary tooth with minute serrations on the distal convex part (fig. $\mathrm{j}$ ). Acicula number 4 in anterior

from same parapodium, $\times 950 ; \mathrm{f}, \mathrm{g}$, unidentate compound setae from median parapodium, $\times 950 ; \mathrm{h}$, thick unidentate compound seta from posterior parapodium, $\times 950$; $i$, slender unidentate compound seta from same parapodium, $\times 950 ; j$, superior simple seta from same parapodium, $\times 950 ; \mathrm{k}$, inferior simple seta from same parapodium, $\times 950 ; 1$, acicula from median parapodium, $\times 740$. 

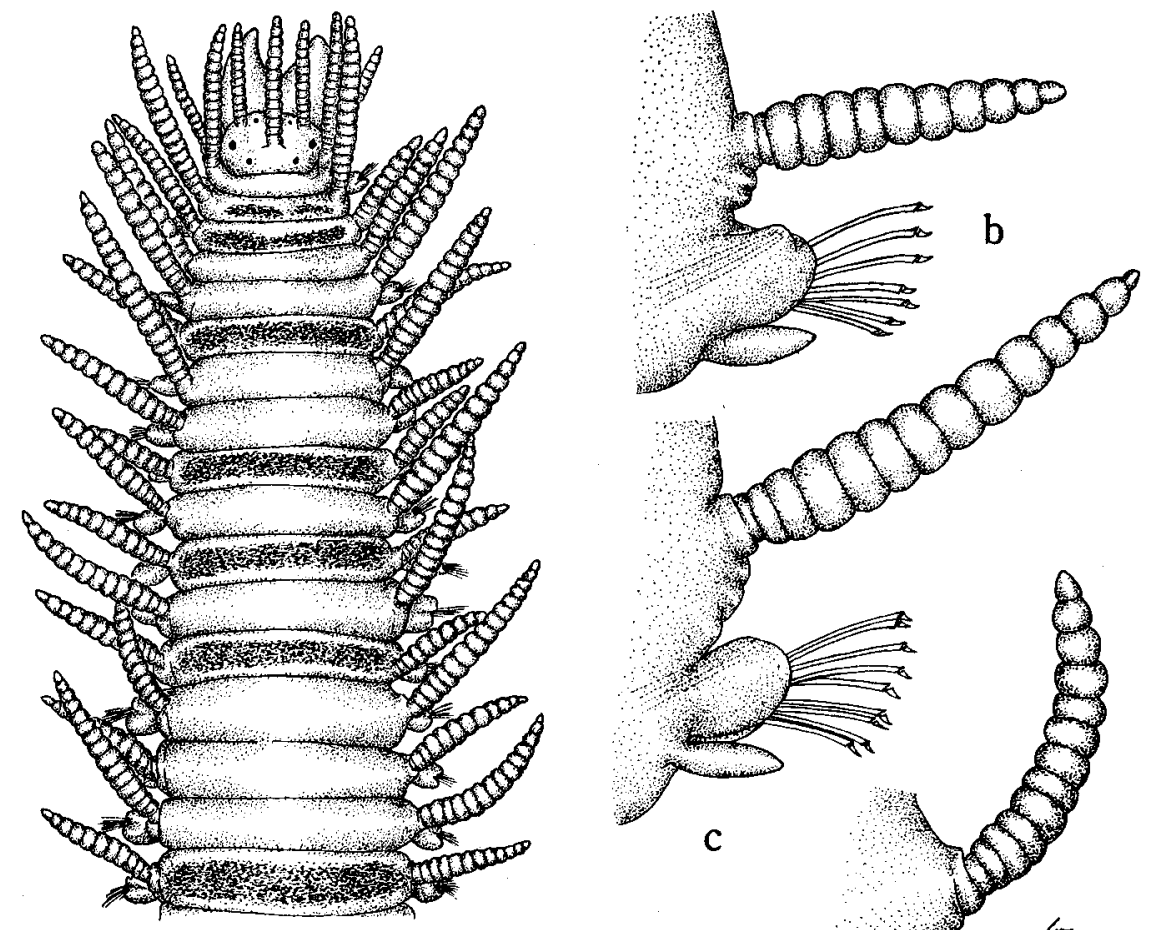

a
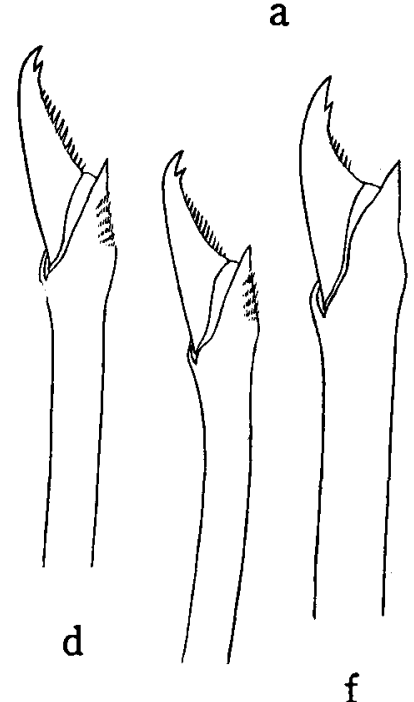

e
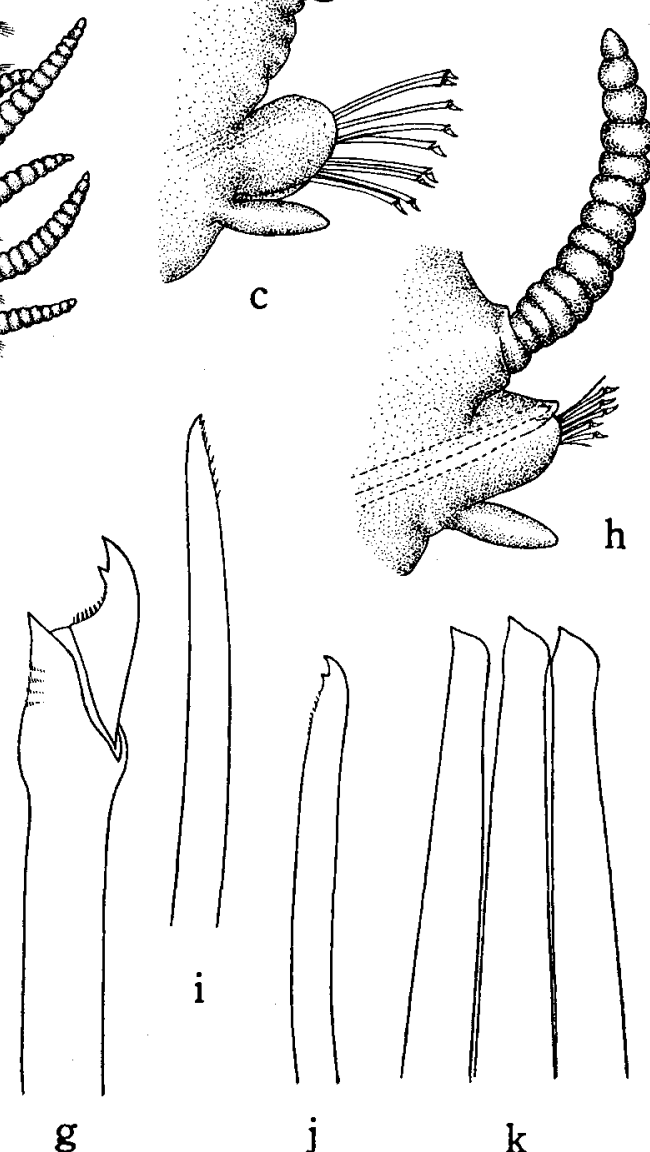

h

d

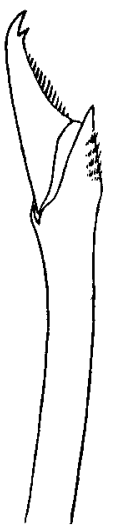

Text-fig. 57. Typosyllis hyalina (GRUBE). a, anterior end, in dorsal view, $\times 35$; $\mathrm{b}$, median parapodium with short dorsal cirrus, in posterior view, $\times 95 ; \mathrm{c}$, median parapodium with long dorsal cirrus, in same view, $\times 95$; $\mathrm{d}$, superior compound seta from 10th parapodium, $\times 950$; e, inferior compound seta from same parapodium, $\times 950 ; \mathrm{f}$, compound seta from median parapodium, $\times 950 ; \mathrm{g}$, compound seta from posterior parapodium, $\times 950$; $\mathrm{h}$, posterior parapodium, $\times 95 ; \mathbf{i}$, superior simple seta from posterior parapodium, $\times 950$; $\mathrm{j}$, inferior simple seta from same parapodium, $\times 950$; $\mathrm{k}$, acicula from median parapodium, $\times 800$. 
parapodium and decrease gradually in number to one in posterior segments; each is mallet-headed (fig. $\mathrm{k}$ ).

The following species have short dorsal cirri with fewer than 20 articles and bidentate composite setae throughout body: Typosyllis aciculata orientalis Imajima and Hartman, T. augeneri Haswell, T. capensis (MaIntosh), T. hyalina (Grube), $T$. torquata (MARION and BoBretsky), T. melanopharyngea (AUGENER) and T. curticirris (Monro). Dorsal color patterns vary or are absent. $T$. hyalina is translucent, has no color markings, or has irregular reddish bands on anterior segments, or transverse red bands.

The species is new to Japan.

Distribution: Mediterranean Sea; Vancouver Island, Canada; California; Panama; North Atlantic Ocean; northern and central Japan.

\section{Typosyllis alternata (MOORE, 1908)}

(Text-fig, 58, a-1)

Syllis alternata Moore, 1908, pp. 323-325, figs. a-f; BERKELEY and BERKeley, 1938, pp. 37-38; 1948, pp. 77-78, fig. 115.

Typosyllis alternata HARTMAN, 1948, p. 21.

Syllis (Typosyllis) alternata Uschakov, 1955, p. 180, fig. 50, z-1.

Collection: Notsuka, in Rishiri Island; Shirikishinai; off Cape Shiriyazaki, in $350 \mathrm{~m}$; Hakodate; Matsumae; Irika; Yoichi; Tokoro, in $30 \mathrm{~m}$; Seto; Tamano; Mukaishima; Usa, in intertidal zone.

Description: The largest specimen is $23 \mathrm{~mm}$ long and $0.8 \mathrm{~mm}$ wide, excluding parapodia, and has 110 setigerous segments. The dorsum is yellowish white and has no color markings. The prostomium is subtriangular and has two pairs of pale orange eyes (fig. a). The median antenna arises between the anterior eyes and has 25 annulations. Lateral antennae arise from the anterior margin of the prostomium; each has 17 to 18 annulations. Paired palpi are about as long as the prostomium is wide; they are fused only at the bases. The pharynx is distally surrounded by 10 soft papillae; the inner wall has a large, subdistal tooth. The proventriculus extends from segment $11-13$ to $17-21$, through 7 to 9 segments. The tentacular segment is about half as long as the second segment; its dorsal tentacular cirrus is about as long as the median antenna, and the ventral one is about half as long as the dorsal one. The first dorsal cirrus is longer than those following and has 35 annulations. The second is short with 17 annulations, the third and fourth are again long with 21 to 28 annulations. The dorsal cirri in the median region of the body are slender and distinctly annulated, alternately long with about 20, and short with 15 articles, in a specimen from Shirikishinai (figs. b, c) or 13 and 10, in a specimen from Seto (fig. d). The long cirri are about as long as the body is wide. A normal parapodium is bluntly conical and has a fascicle of compound setae. Setae in anterior parapodia number 
M. IMAJIMA

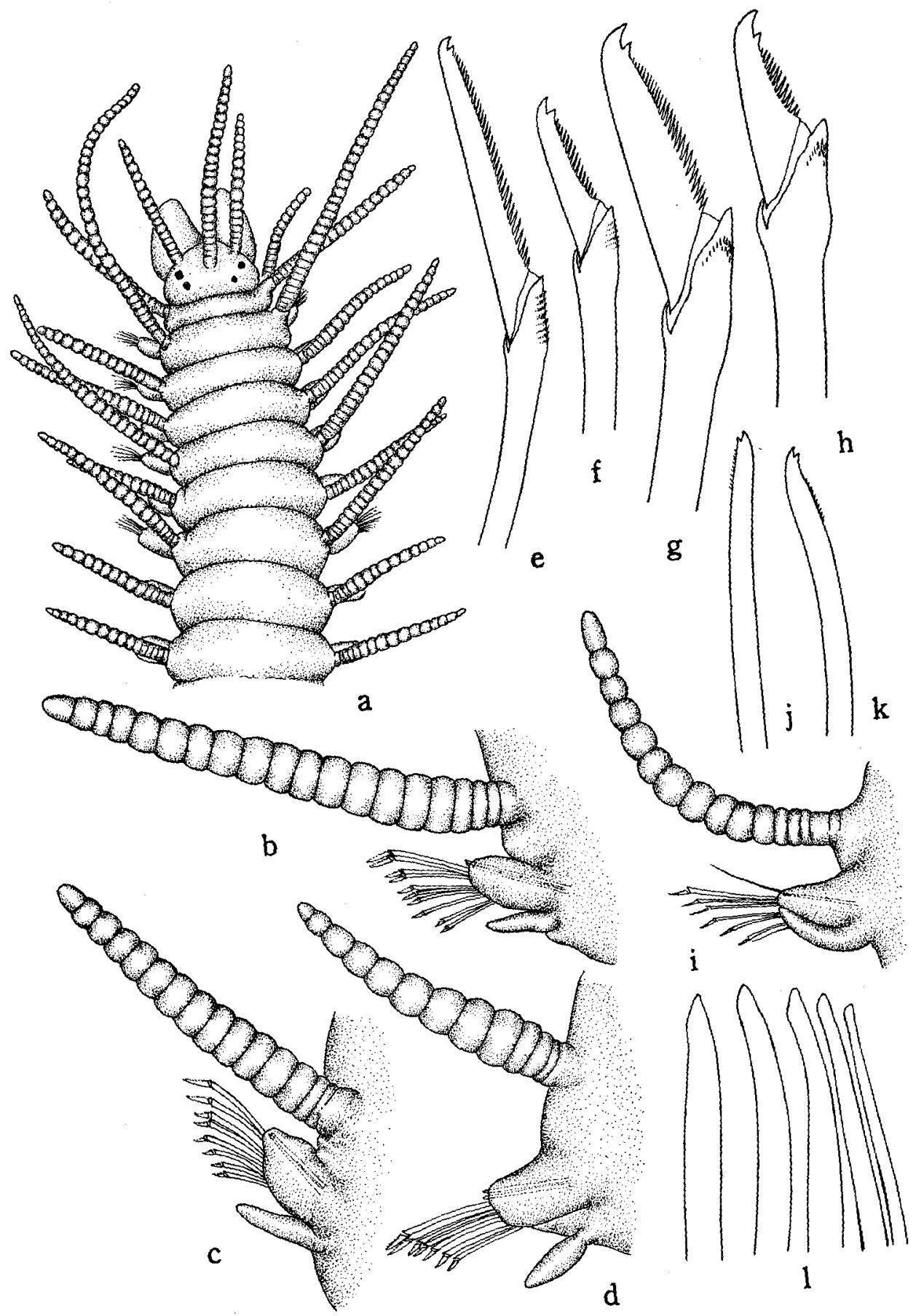


about 10 in a fascicle; each is slender, distinctly bidentate and the superior appendage is about twice as long as the inferior one, with large serrations along the cutting edge (figs. e, f). Those in median parapodia are thicker and the superior appendages are about 1.5 times as long as the inferior ones (figs. $g, h$ ). In posterior parapodia dorsal cirri are more distinctly annulated. Their setal fascicle are similar to those in front (fig. i), except that they have two simple setae, one in superior, the other in inferior position, both distinctly bifid, with minute serrations on one side (figs. j, k). Acicula number 5 in anterior parapodia (fig. l) and decrease gradually in number to one in posterior segments. The ventral cirrus is short, digitate and does not extend beyond the parapodium. The pygidium has two long anal cirri.

The species is new to Japan.

Distribution: Alaska; California; Vancouver Island; north-west Japan Sea; Japan.

\section{Typosyllis aciculata orientalis IMAJIMA and HARTMAN, 1964}

Typosyllis aciculata orientalis Imajima and Hartman, 1964, pp. 130-132, pl. 31, figs. e, f; pl. 32, figs. a-t. Syllis closterobranchia FAUveL, 1934, p. 306.

Typosyllis? closterobranchia Imajima and Hartman, 1964, p. 138.

Collection: Shirikishinai, between holdfasts of Laminaria, boring holes in Mytilus, in Porifera, from littoral zone to $140 \mathrm{~m}$; off Cape Shiriyazaki, from $330 \mathrm{~m}$; Utabetsu; Atsuga; Harutachi; Erimo; Akkeshi; Hakodate; Moheji; Fukushima; Matsumae, from encrusting coralline algae; Tomari; Sawaki; Yoichi; Notsuka; Funadomari; Saroma Lake; Saruru, in $30 \mathrm{~m}$; Asamushi; Onagawa; Misaki; Tokyo Bay, in 20-80 m; Sugashima; Seto; Mukaishima; Tamano; Usa; Amakusa; Ariake Sea, in $20 \mathrm{~m}$; Noto-ogi.

Description: The largest specimen measures $42 \mathrm{~mm}$ long and $1.3 \mathrm{~mm}$ wide including parapodia; it consists of 160 setigerous segments. The dorsum has two black, parallel, transverse lines on each segment or the lines entire in anterior and broken in posterior segments. The three antennae of the prostomium are distinctly articulated and each has 10 to 15 annulations. The dorsal cirri in the anterior region, except the first one, are slender and each has 11 to 15 annulations. Those in the median region are thick at their bases and each has 8 to 10 annulations. Setae are compound falcigers; those in the anterior and posterior regions have a subdistal, secondary tooth and the cutting margin has coarse serrations; appendages of the

Text-fig. 58. Typosyllis alternata (Moore). a, anterior end, in dorsal view, $\times 35 ; \mathrm{b}$, median parapodium with long dorsal cirrus in specimen from Shirikishinai, in posterior view, $\times 120$; c, median parapodium with short dorsal cirrus in same specimen, in same view, $\times 120$; d, median parapodium in specimen from Seto, in same view, $\times 95$; e, superior compound seta from anterior parapodium, $\times 950$; $f$, inferior compound seta from same parapodium, $\times 950 ; \mathrm{g}$, superior compound seta from median parapodium, $\times 950 ; \mathrm{h}$, inferior compound seta from same parapodium, $\times 950$; i, posterior parapodium, $\times 120$; $\mathrm{j}$, superior simple seta from posterior parapodium, $\times 950 ; \mathrm{k}$, inferior simple seta from same parapodium, $\times 950 ; 1$, acicula from anterior parapodium, $\times 950$. 
superior setae are longer than those in the inferior position. Setae in the median region are thicker than those in anterior and posterior regions, and have a short appendage with a small accessory tooth. Posterior parapodia have also two simple setae; one in superior, and one in inferior position; the superior one is just above the aciculum and has an entire tip or a small, secondary tooth; the inferior one is distinctly bifid. Acicula number 5 in anterior and median parapodia and decrease gradually to one posteriorly.

This species resembles T. armillaris (MüLleR, 1771) from Greenland in many characteristics; the first is distinguished from the second as follows: (1) compound setae in the median region have an accessory tooth, instead of being unidentate; (2) posterior parapodia have two simple setae in superior and inferior positions, instead of only one, and (3) acicula number 1 to 5 , instead of 1 to 2.

Through the courtesy of the Museum National d'Histoire Naturelle in Paris, a specimen of Syllis armillaris from Algérie, identified by Fauvel (1942), was examined. The specimen agrees with $T$. aciculata orientalis in all respects, and differs from Syllis armillaris (MüLler). Specimens of Syllis closterobranchia FAuvel (1934) from Seto were re-examined; they also agree with Typosyllis aciculata orientalis.

Distribution: Northern to southern Japan; Algérie.

\section{Typosyllis fasciata (MALMGREN, 1867)}

Syllis fasciata MALMGRen, 1867, p. 43, pl. 8, fig. 47, pl. 9, fig. 52; WesenberG-Lund, 1947, p. 10, textfig. 2a; Berkeley and Berkeley, 1948, p. 74, textfigs. 109-110; Uschakov and Wu, 1962, p. 58. Syllis (Typosyllis) fasciata Uschakov, 1955, p. 180, textfigs. 46, 51.

Typosyllis fasciata Imajma and Hartman, 1964, pp. 135-136, pl. 33, figs. j-o.

Collection: Shirikishinai, in intertidal zone; Ariake Sea, in $20 \mathrm{~m}$.

Diagnosis: The largest specimen measures $14 \mathrm{~mm}$ long and $1.3 \mathrm{~mm}$ wide for 82 setigerous segments. The prostomium is subglobular and its posterior part is partly covered by occipital elevations arising from the first segment. Each median and lateral antenna has 30 to 35 annulations. The pharynx terminates in $10 \mathrm{soft}$ papillae and its inner wall has a middorsal tooth near its anterior margin. Dorsal cirri alternate in length; the short have 25 to 30 , and the long 45 to 50 annulations. All setae are unidentate composite, with serrations along the cutting margin. Posterior parapodia have one additional simple seta in the superior position of the fascicle; it is distally obscurely bifid and minutely serrated at one side.

Syllis fasciata (FAUVEL, 1934) from Misaki and Seto are referred to Typosyllis ehlersioides MARENZELLER.

Distribution: North Atlantic and Pacific Oceans; Okhotsk Sea; Bering Sea; North Japan Sea; Yellow Sea; Japan. 


\section{Typosyllis adamanteus kurilensis CHLEBovitsch, 1959}

Typosyllis adamanteus kurilensis Imajima and Hartman, 1964, pp. 134-35, pl. 33, figs. a-i.

Collection: Shirikishinai; Erimo; Yoichi; Notsuka, in Rebun Island; Sugashima; Tamano; Mukaishima, in intertidal zone.

Diagnosis: The largest specimen measures $52 \mathrm{~mm}$ long and $1.8 \mathrm{~mm}$ wide for 150 setigerous segments. The dorsum of each segment is brown and has a middorsal, transversely oval white spot. The dorsal color of specimens from Sugashima, Tamano and Mukaishima is more dilute than that from Hokkaido. The dorsal cirri are slender and distinctly annulated in the median region of the body, alternately long with about 35, and short with 22 annulations. Setae are unidentate compound falcigers with hooked tips and large serrations along the cutting margin.

Distribution: Japan; Kurile Islands.

\section{Typosyllis maculata $\mathrm{n}$. sp.}

(Text-fig. 59, a-m)

Syllis exilis Fauved, 1934, p. 305.

Collection: Seto; Noto-ogi, in intertidal zone.

Description: The largest specimen measures $17 \mathrm{~mm}$ long and $1 \mathrm{~mm}$ wide including parapodia; it consists of 81 setigerous segments. The body is yellow and has no color markings. Antennae, tentacular cirri and dorsal cirri are distinctly annulated; every third or fourth annulus is black on the ventral side (fig. a) and not pigmented dorsally (fig. c). The prostomium is subgloblar and broader than long; there are two pairs of orange colored eyes in trapezoidal arrangement and the anterior pair is slightly larger than the posterior one (fig. b). Palpi are subtriangular and about as long as the prostomium; they are fused at the bases. A median antenna arises from the center of the prostomium; it is more than twice as long as the prostomium and has 24 annulations. Lateral antennae arise from the anterior margin of the prostomium and each has 19 to 21 annulations. The pharynx is distally surrounded by 10 soft papillae and has a subdistal middorsal tooth in its inner wall. The proventriculus extends from setigerous segment 9 to 15 . Dorsal tentacular cirri are about 1.5 times as long as the median antenna and each has 35 to 37 annulations. The ventral ones are about two-thirds as long as the dorsal one. The first dorsal cirri are about twice as long as the lateral antennae and have 35 to 37 annulations. The second and third cirri are short and have 25 to 28 annulations. The fourth ones are long with 38 to 40 annulations. Afterward, they slightly alternate long and short; in median region they are short with 40 (fig. c) to long with 43 annulations (fig. d). A normal parapodium is bluntly conical and terminates in triangular lobes in pre- and postsetal ends. The setal fascicle emerges between the two lobes. In anterior parapodia the superior setae have long bidentate appendages with serrations 


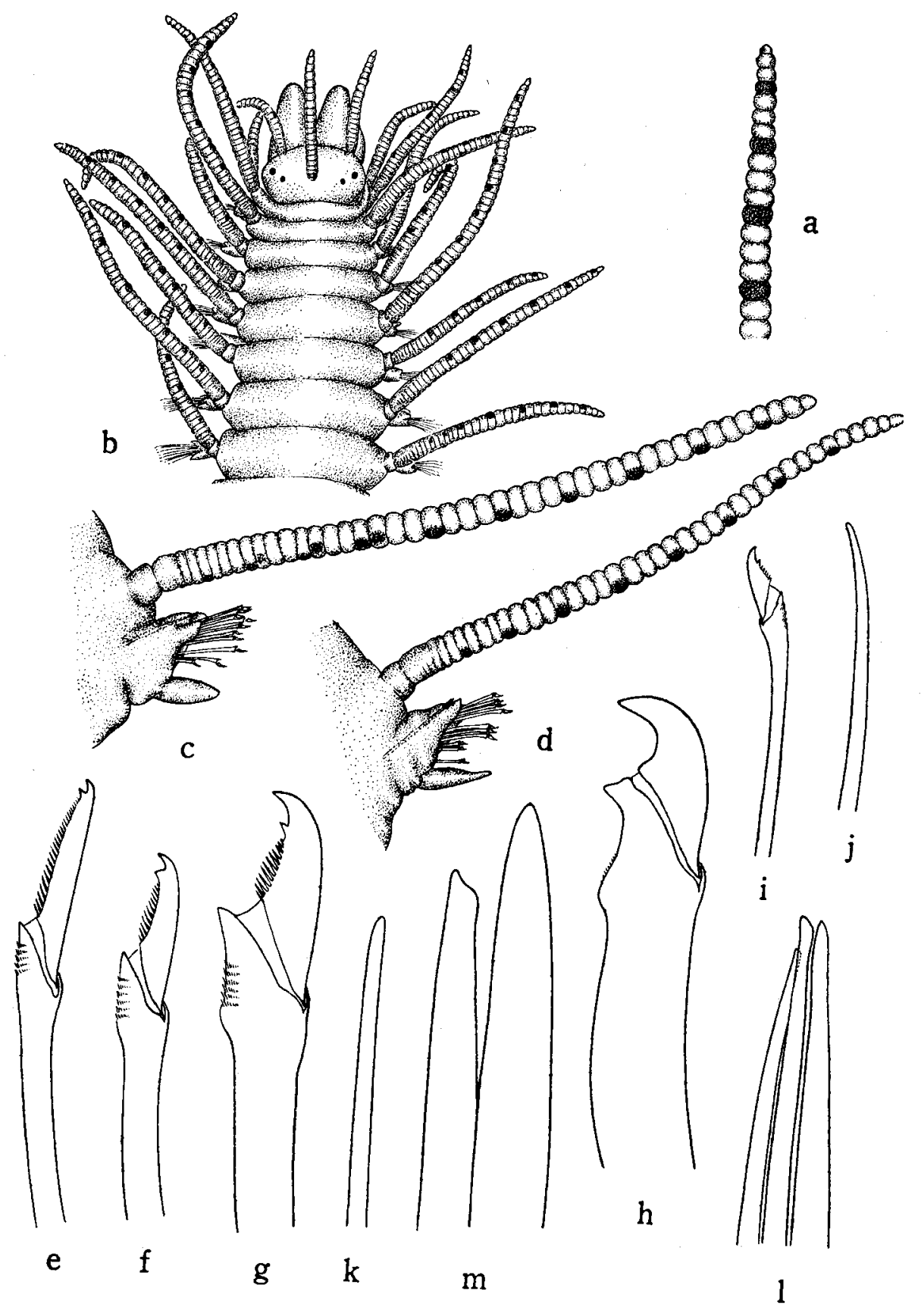

Text-fig. 59. Typosyllis maculata n. sp. a, a distal part of dorsal cirrus, in ventral view, $\times 75$; $\mathrm{b}$, anterior end, in dorsal view, $\times 35$; c, median parapodium with long dorsal cirrus, in anterior view, $\times 75$; $d$, median parapodium with short dorsal cirrus, in same view, $\times 75$; 
along the cutting margins (fig. e); inferior appendages are about three-fourths as long as the superior ones (fig. f). Setae in median segments are thicker than those in front and are of two kinds; 6 to 7 superior setae have a subdistal secondary tooth and serrations along the cutting margins (fig. g); 2 to 3 inferior setae have a falcate appendage without secondary tooth and serrations (fig. h). In posterior parapodia the compound setae are slender with short appendages and an accessory tooth (fig. i). In addition, there are two simple setae, one in superior and one in inferior position (figs. j, k); both have entire tips and the superior one is distally curved. Acicula number 3 in anterior parapodia; each is slender and has a blunt tip (fig. l); those in the median region number 2 , with one thicker than the other and terminating in a pointed tip, which protrudes from the acicular lobe; the other one is mallet-headed (fig. $\mathrm{m}$ ). Ventral cirri are digitate and slightly longer than the setigerous lobe. The pygidium has long anal cirri.

Typosyllis maculata resembles T. cirropunctata (MicheL, 1909) from the Mediterranean Sea. The two have similar antennae, and dorsal cirri have pigmented annulations at intervals throughout their length. T. maculata differs in the following respects: (1) annulations in antennae and dorsal cirri are ventrally pigmented on every fourth ring instead of nearly alternately with the pigment not limited to the ventral side of the ring; (2) compound setae are all bidentate except for 2 to 3 inferior setae in median region, instead of all unidentate.

T. maculata resembles T. exilis Gravier (1900) from the Red Sea in having two kinds of composite setae in median parapodia. But the antennae and the dorsal cirri of $T$. exilis have no pigmented annulations.

T. maculata also resembles Syllis (Typosyllis) annularis VerRILI (1900) from Bermuda Islands in having dorsal cirri with pigmented rings on every fourth. However, in $T$. annularis the anterior parapodia have a fascicle of compound setae with minutely bidentate tips in superior and with acute, claw-like tips in inferior position, instead of having all large secondary teeth. More posterior parapodia have curved appendages with strongly incurved acute tips, instead of two kinds. Typosyllis exilis Fauvel (1934) from Seto is referred to the species because dorsal cirri have regularly arranged, pigmented annulations.

Distribution: Southern Japan.

Typosyllis ehlersioides MARENZELLER, 1890

(Text-fig. 60, a-o)

Typosyllis ehlersioides MARENzeller, 1890, pp. 4-5, fig. a.

e, superior compound seta from 1 st parapodium, $\times 950$; $f$, inferior compound seta from same parapodium, $\times 950 ; \mathrm{g}$, superior compound seta with a secondary tooth from median parapodium, $\times 950 ; \mathrm{h}$, inferior unidentate compound seta from same parapodium, $\times 950 ; \mathrm{i}$, compound seta from posterior parapodium, $\times 950 ; \mathrm{j}$, superior simple seta from same parapodium, $\times 950$; $\mathbf{k}$, inferior simple seta from same parapodium, $\times 950$; 1 , acicula from 1 st parapodium, $\times 800 ; \mathrm{m}$, acicula from median parapodium, $\times 800$. 
Syllis (Typosyllis) Krohnii FAuveL, 1934, pp. 303-304.

Syllis fasciata FAUvel, 1934, pp. 304-305.

Collection: Shirikishinai; Izumisawa; Atsuga; Harutachi; Irika; Onagawa; Misaki; Sugashima; Seto; Tamano; Usa; Amakusa; Ariake Sea, in 20 m; Noto-ogi.

Description: The largest specimen measures $25 \mathrm{~mm}$ long and $1.5 \mathrm{~mm}$ wide including parapodia; it consists of 100 setigerous segments. The middle dorsum of each segment has a transverse chocolate-colored band with the anterior part pale and the posterior part white (fig. a). The prostomium is wider than long and has two pairs of reddish eyes in trapezoidal arrangement. The anterior eyes are larger than the posterior ones. The frontal part of the prostomium is chocolate colored. A median antenna arises from the center of the prostomium and is about seven times as long as the prostomium; it has 40 annulations; its basal part is indistinctly annulated. Lateral antennae are inserted at the anterior margin of the prostomium and each is about half as long as the median one. Palpi are subtriangular and are fused at their bases. The pharynx terminates in 10 to 12 soft papillae and has a spindle-shaped, middorsal tooth (fig. b). The proventriculus extends from setigerous segment 14-16 to 23-28. Dorsal tentacular cirri are about as long as the dorsal ones. The first dorsal cirri are about 1.5 times the length of the median antenna; they have 70 to 75 annulations. On the median segments the dorsal cirri alternate long and short, having about 35 (fig. c) and 70 annulations (fig. d). All dorsal cirri are slender and annulations become basaly indistinct. Parapodia are bluntly conical and have fascicles of compound setae with an accessory subdistal tooth. In anterior parapodia the appendages of the superior setae are longer than those of inferior ones; each has long serrations along the cutting margin (figs. e, f). Setae in median are thicker than those in anterior segments, and have a slenderer accessory tooth (fig. g). On posterior parapodia the dorsal cirri have 30 to 35 annulations and setae are composite with two additional simple setae (fig. h). The setal appendages are short and similar to those in median parapodia but smaller (figs. $\mathbf{i}, \mathbf{j}$ ). The two simple setae are present in superior- and inferior-most parts of the fascicles; the superior one is just above the aciculum and has a bifid tip and fine serrations along one side of the shaft (fig. $\mathbf{k}$ ); the inferior seta has a small, subdistal secondary tooth (fig. 1). Acicula number 5 in a median parapodium (fig. $m$ ) and decrease gradually in number to one in posterior segments; each has rounded tip (fig. $n$ ). Ventral cirri are digitate and do not extend beyond the tips of the setigerous lobes. The pygidium has two long anal cirri.

The asexual buds arise between setigerous segment 53 and 86 of the stem form (fig. o); young stolons consist of 22 to 27 setigerous segments.

Text-fig. 60. Typosyllis ehlersioides Marenzeller. a, anterior end, in dorsal view, $\times 18$; $\mathrm{b}$, distal part of pharynx opened by dissection, $\times 32$; $\mathrm{c}$, median parapodium with short dorsal cirrus, in anterior view, $\times 32$; $\mathrm{d}$, median parapodium with long dorsal cirrus, in same view, $\times 32$; e, superior compound seta from 10 th parapodium, $\times 700 ; \mathrm{f}$, inferior compound seta from same parapodium, $\times 700 ; \mathrm{g}$, compound seta from median parapodium, $\times 840 ; \mathrm{h}$, posterior parapodium, $\times 840 ; \mathrm{i}, \mathrm{j}$, compound setae from posterior 


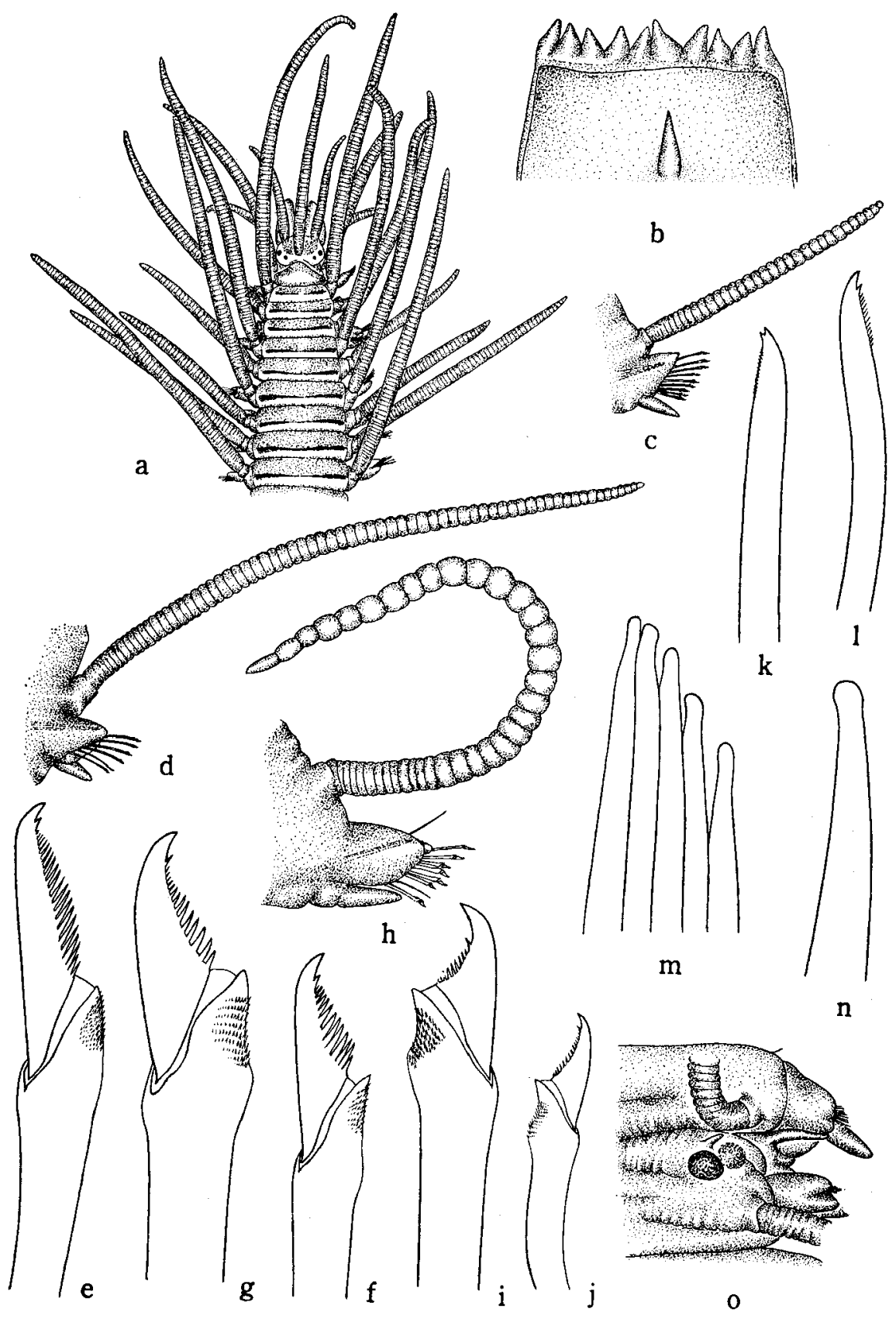

parapodium, $\times 840 ; \mathrm{k}$, superior simple seta from same parapodium, $\times 840 ; 1$, inferior simple seta from same parapodium, $\times 840 ; \mathrm{m}$, acicula from median parapodium, $\times 420$; $\mathrm{n}$, aciculum from posterior parapodium, $\times 420 ; 0$, newly formed head showing two antennae and two eyes, in dorsal view, $\times 50$. 
Two specimens of Syllis (Typosyllis) Krohnii Fauvel (1934, p. 303) from Misaki were re-examined. They have characters of the present species. Four complete specimens and four anterior fragments of Syllis fasciata FAuvel (1934, p. 304) from Misaki and Seto were re-examined. The largest one measures $10 \mathrm{~mm}$ long and 0.7 $\mathrm{mm}$ wide for 60 setigerous segments. The body is yellow without color band or this slightly visible, and setae are composite with an accessory tooth; posterior parapodia have two additional simple setae. They correspond with those of $T$. ehlersioides except that they lack the dorsal color pattern; this may disappear in alcohol.

The species is new to Japan.

Distribution: Bering Sea; northern to southern Japan.

\section{Typosyllis lunaris n. sp.}

(Text-fig. 61, a-n)

Collection: Seto, in intertidal zone.

Description: The largest specimen measures $30 \mathrm{~mm}$ long and $1.5 \mathrm{~mm}$ wide including parapodia; it consists of 130 setigerous segments. The dorsum is brown and each segment has a middorsal, transversely oval white spot; these spots become indistinct posteriorly (fig. a). In life anterior dorsal cirri are brown but this fades in preserved specimens. The prostomium is subglobular and wider than long. There are two pairs of reddish eyes in trapezoidal arrangement; the anterior eyes are about twice as large as the posterior ones. A median antenna arises between the posterior eyes of the prostomium and is about six times as long as the prostomium; it has 35 annulations. Lateral antennae emerge from the anterior margin of the prostomium; each is about half as long as the median antenna. Palpi are elongate triangular and as long as the prostomium is wide; they are fused at the bases. The pharynx is distally surrounded by 10 soft papillae and has a subdistal, middorsal tooth (fig. b). The proventriculus extends from setigerous segment 15-17 to 20-23, through 6 or 7 segments. The anterior part of the tentacular segment is flap-like and covers the posterior part of the prostomium. The dorsal tentacular cirri are slightly shorter than the median antenna, and the ventral cirri are about half as long as the dorsal ones. The first dorsal cirri are longer than the median antenna and each has 37 to 40 annulations. The second cirri are about half as long as the first ones. More posterior dorsal cirri alternate short and long, with the long cirri thicker than short ones. Median dorsal cirri are long with 40, or short with 20 annulations; the long cirri

Text-fig. 61. Typosyllis lunaris n. sp. a, anterior end, in dorsal view, $\times 28$; b, distal part of pharynx opened by dissection, $\times 42$; $c$, median parapodium with Iong dorsal cirrus, in anterior view, $\times 42$; d, median parapodium with short dorsal cirrus, in same view, $\times 42$; e, superior compound seta from 1 st parapodium, $\times 840$; $f$, inferior compound seta from same parapodium, $\times 840$; g, compound seta from median parapodium, $\times 840 ; \mathrm{h}$, superior compound seta from posterior parapodium, $\times 840$; i, inferior compound seta from same parapodium, $\times 840 ; \mathrm{j}$, superior simple seta from same parapodium, $\times 840$; $\mathrm{k}$, inferior 


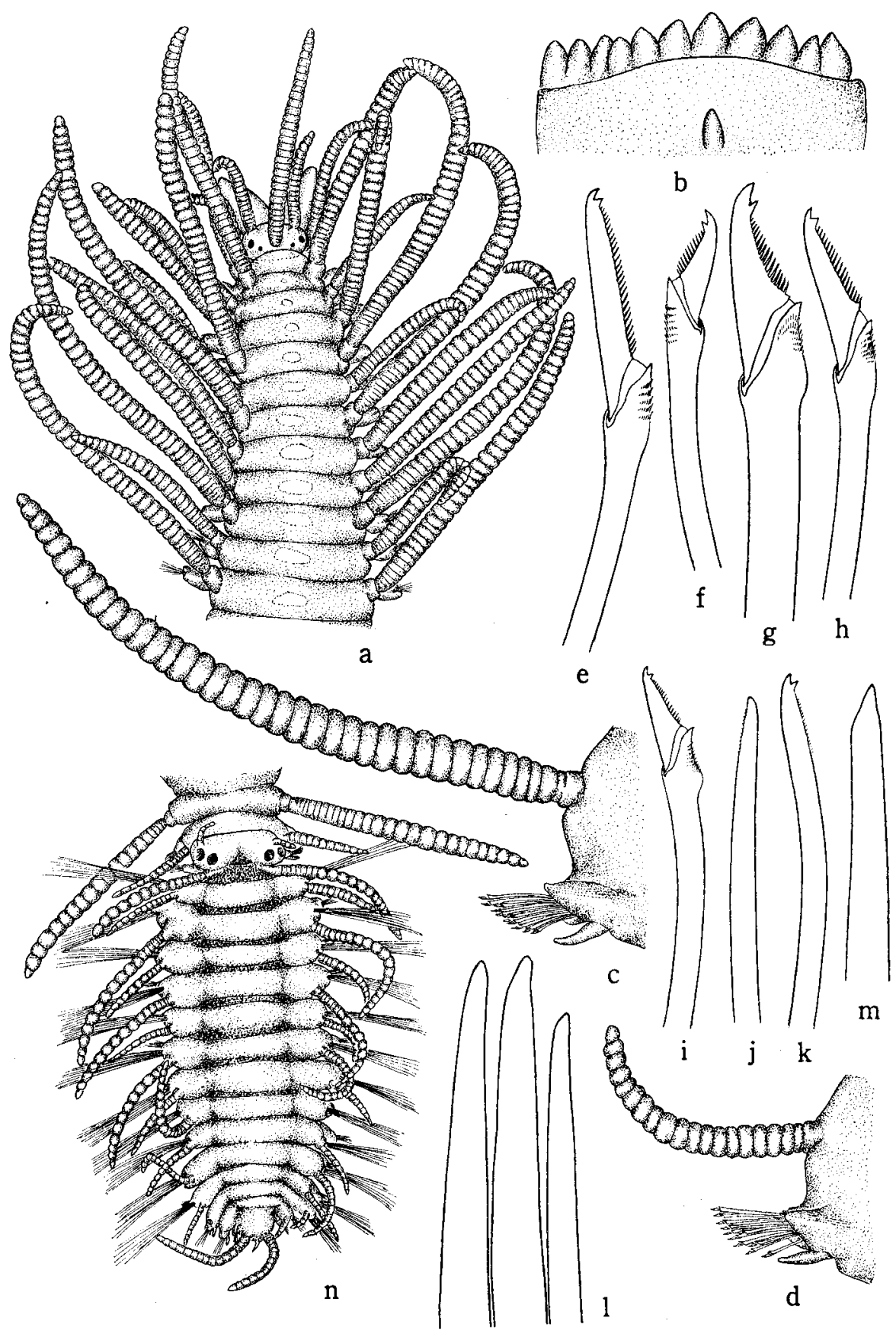

simple seta from same parapodium, $\times 840 ; 1$, acicula from median parapodium, $\times 840 ; \mathrm{m}$, aciculum from posterior parapodium, $\times 840$; $\mathrm{n}$, newly formed budding individual, in dorsal view, $\times 32$. 
(fig. c) are about 2.5 times as long as, and about two-thirds as wide as, the short cirri (fig. d). Parapodia are bluntly conical and have a fascicle of bidentate compound setae. Anterior superior setae have longer appendages than those more inferior, with serrations along the cutting margins (figs. e, f). Setae in median parapodia are thicker than those of anterior parapodia; all appendages are subequal (fig. g). Setae in posterior parapodia are similar to those anterior, but appendages of superior ones are shorter (figs. h, i). Posterior fascicles also contain two simple setae, one in superior, the other in inferior position. The superior one terminates in a rounded tip (fig. $\mathrm{j}$ ) and the inferior one is distinctly bifid (fig. $\mathrm{k}$ ) ; both kinds have minute serrations along one side. Acicula number 3 in a median parapodia and dec rease gradually in number to one in posterior segments; each has a blunt tip (figs. $1, \mathrm{~m}$ ).

An asexual bud is proliferated posteriorly from the stock behind setigerous segments 87 to 109 , and newly formed budding individuals consist of 15 to 21 segments (fig. n); each with a body wider than that of the stem. The dorsum is brownish, and the first segment and inter segmental spaces of the segments are dark brown. Swimming setae arise from the second segment between dorsal cirri and setigerous lobes.

Typosyllis lunaris is characterized as follows: (1) the dorsum is brown and each segment has an oval white spot; (2) dorsal cirri have brown spots and are alternately short and long, slender and broad; (3) setae are all bidentate composites and (4) an asexual bud is proliferated from setigerous segments 87 to 109 ; it consists of 15 to 21 segments.

The species is similar to Typosyllis adamanteus kurilensis ChLebovitsch (1959) in having oval segmental white spots on the dorsum. However, the latter has unidentate setae in the anterior and median parapodia.

Distribution: Southern Japan.

\section{Typosyllis setoensis $\mathrm{n} . \mathrm{sp}$.}

(Text-fig. 62, a-l)

Collection: Seto, in intertidal zone.

Description: The largest individual measures $26 \mathrm{~mm}$ long and $1.2 \mathrm{~mm}$ wide for 110 setigerous segments. The body is yellow and lacks color markings. The prostomium is subrectangular and has two pairs of reddish eyes in trapezoidal arrangement (fig. a). A pair of nuchal lappets are present along the posterior margin of the prostomium. A median antenna arises from the center of the prostomium; it is about four

Text-fig. 62. Typosyllis setoensis $\mathrm{n} . \mathrm{sp}$. a, anterior end, in dorsal view, $\times 35 ; \mathrm{b}$, median parapodium with long dorsal cirrus, in posterior view, $\times 80 ; \mathrm{c}$, median parapodium with short dorsal cirrus, in same view, $\times 80$; d, superior compound seta from 1st parapodium, $\times 950$; $e$, inferior compound seta from same parapodium, $\times 950 ; f$, superior compound seta from median parapodium, $\times 950$; , inferior compound seta from same parapodium, $\times 950$; 

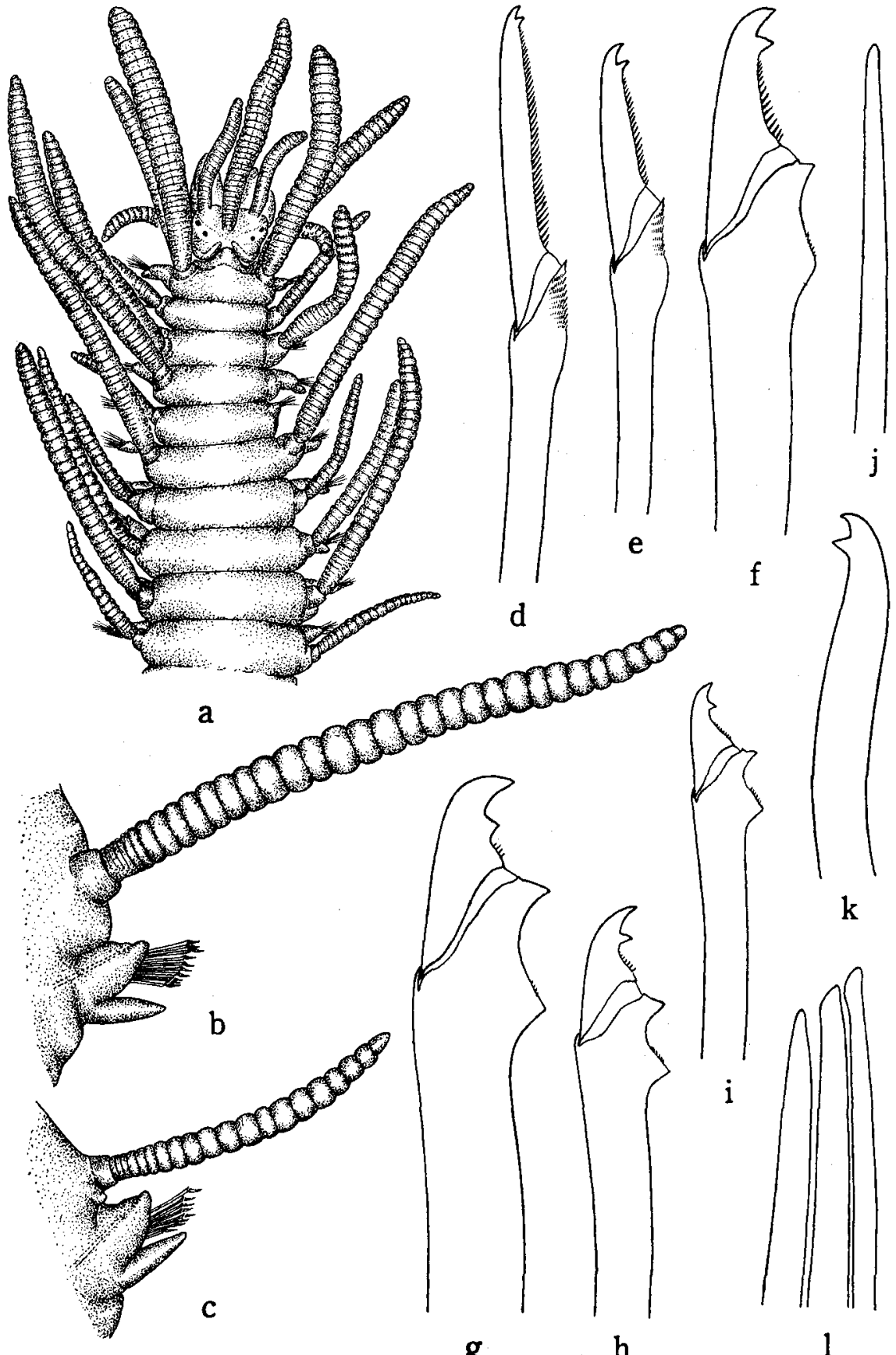

$\mathrm{h}$, superior compound seta from posterior parapodium, $\times 950 ; \mathrm{i}$, inferior compound seta from same parapodium, $\times 950 ; j$, superior simple seta from same parapodium, $\times 950$; $\mathrm{k}$, inferior simple seta from same parapodium, $\times 950$; , acicula from anterior parapodium, $\times 950$. 
times as long as the prostomium and has 35 annulations; it is thickest medially and tapers to both ends. Lateral antennae are inserted at the anterior margin of the prostomium and each is about half as long as the median one. Palpi are subtriangular and fused at their bases; they are about as long as the prostomium. The pharynx is surrounded by 10 soft papillae and has a middorsal tooth in its inner wall. The proventriculus extends from setigerous segment 5 to 8 . Dorsal tentacular cirri are about as long as the median antenna and the ventral ones are about half as long as the dorsal ones. The first dorsal cirri are much thicker than the following cirri and each has about 40 annulations. In more posterior segments the dorsal cirri alternate long and short; in median segments they have 33 and 20 annulations, with the short one (fig. c) about two-thirds as thick as the long one (fig. b). Parapodia are subconical, and provided with bidentate compound setae. Setae in anterior parapodia have long appendages with serrations along the cutting margins; superior appendages (fig. d) are about 1.5 times as long as the inferior ones (fig. e). Setae in median parapodia are thicker than those in anterior segments and each has a thick, short appendage with a large, secondary tooth; the cutting margins of the superior appendages (fig. $f$ ) are longer than those in inferior ones (fig. g). The secondary tooth in inferior appendages occurs about midway between the tip and its base, and serrations on the cutting margin are minute. Their shafts are thickest subdistally. Setae in posterior segments are similar to but slenderer than those in median parapodia (figs. $h, i$ ). In addition, there are two simple setae, one in superior and one in inferior positions; the first is slender with an entire tip (fig. j) and the inferior one is distinctly bifid (fig. k). Acicula number 3 in anterior parapodium (fig. l) and decrease gradually to one.

Typosyllis setoensis resembles Typosyllis krohnii (EHLERs, 1864) from Zurkowa, in having dorsal cirri alternating thick and slender; the anterior cirri especially are much thicker. However, T. setoensis differs from T. krohnii in that (1) the dorsum is yellowish and has no color markings, instead of having a violet-brown streak on anterior segments; (2) setae in the median region are bidentate composite with a large secondary tooth, instead of unidentate; (3) the inferior simple seta of the fascicle in posterior parapodia is distinctly bifid with a large secondary tooth, instead of slightly bifid.

Two specimens of Syllis (Typosyllis) Krohnii Fauvel (1934, p. 303) from Seto were re-examined. They are here referred to T.ehlersioides MAREnzeller, with which they agree in color pattern of the dorsum and compound setae with minute accessory tooth.

Distribution: Southern Japan.

Typosyllis monilata n. sp.

(Text-fig. 63, a-I)

? Syllis torquata Fauved, 1934, pp. 306-307. 
Collection: Misaki; Noto-ogi, in intertidal zone.

Description: The largest specimen measures $21 \mathrm{~mm}$ long and $1.2 \mathrm{~mm}$ wide for 88 setigerous segments. The body is orange and the dorsum of the first and second setigerous segments is black (fig. a). The prostomium is wider than long and two pairs of reddish eyes are in trapezoidal arrangement. Palpi are slightly longer than the prostomium and fused at their bases. A median antenna arises from the center of the prostomium and has 20 annulations. Lateral antennae arise from the anterior part of the prostomium; each is about two-thirds as long as the median antenna, with 11 to 12 annulations. The pharynx is distally surrounded by 10 soft papillae and has a middorsal tooth in in inner wall. The proventriculus extends from setigerous segment 13 to 20. The tentacular segment (=the first segment) is white and has two pairs of tentacular cirri; the dorsal one is slightly longer than the median antennae, with 20 to 22 annulations and the ventral one is about two-thirds as long as the dorsal one. The first dorsal cirri are about two times as long as the lateral antennae, each with 27 annulations. The second and third dorsal cirri are subequal, each with 19 to 20 annulations. The fourth cirri are long with 25 annulations. All other dorsal cirri alternate long and short; in the median region the short (fig. c) have 16 to 17 , and the long 24 to 25 annulations (fig. b) ; all are distinctly annulated. A normal parapodium is bluntly conical and has a fascicle of bidentate compound setae with serrations along the cutting margin. Setae in anterior parapodia are slender and the appendages have a secondary tooth near the tip; superior are longer than the inferior setae (fig. d). Setae in median parapodia are thicker than those in anterior segments and have falcate appendages with a large secondary tooth (fig. e). Posterior parapodia have compound setae and two simple setae (fig. f). The composite setae are of two types: one has a slender shaft with slender appendage (fig. g), and other has a thick shaft and the appendage has a large secondary tooth about midway the length (figs. h, i). Two additional simple setae are present in superior and inferior positions; the superior one is thick and has a bifid tip (fig. $\mathrm{j}$ ), and inferior one is distinctly bifid and has minute serrations on one side (fig. $\mathrm{k}$ ). Acicula number 4 in anterior parapodia (fig. 1) and decrease gradually in number to one in posterior segments. Ventral cirri are digitate and do not extend beyond the setigerous lobes.

Typosyllis monilata resembles $T$. torquata (MARion and BoBretzky, 1875) from the Mediterranean Sea in having anterior two colored segments and fascicles of bidentate setae. However, T. monilata differs from T. torquata in the following features: (1) the colored segments appear on the second and third segments, instead of on the first and second segments; (2) the median antenna has 20 annulations, the dorsal tentacular cirri has 20 to 22 , and dorsal cirri have 16 to 30 , instead of all with 7 to 9 annulations and (3) the palpi, antennae and dorsal cirri are not fringed by short cilia, instead of fringed.

Two specimens of ?Syllis torquata Fauvel (1934) from Misaki were re-examined and are here attributed to this species.

Distribution: Central Japan. 

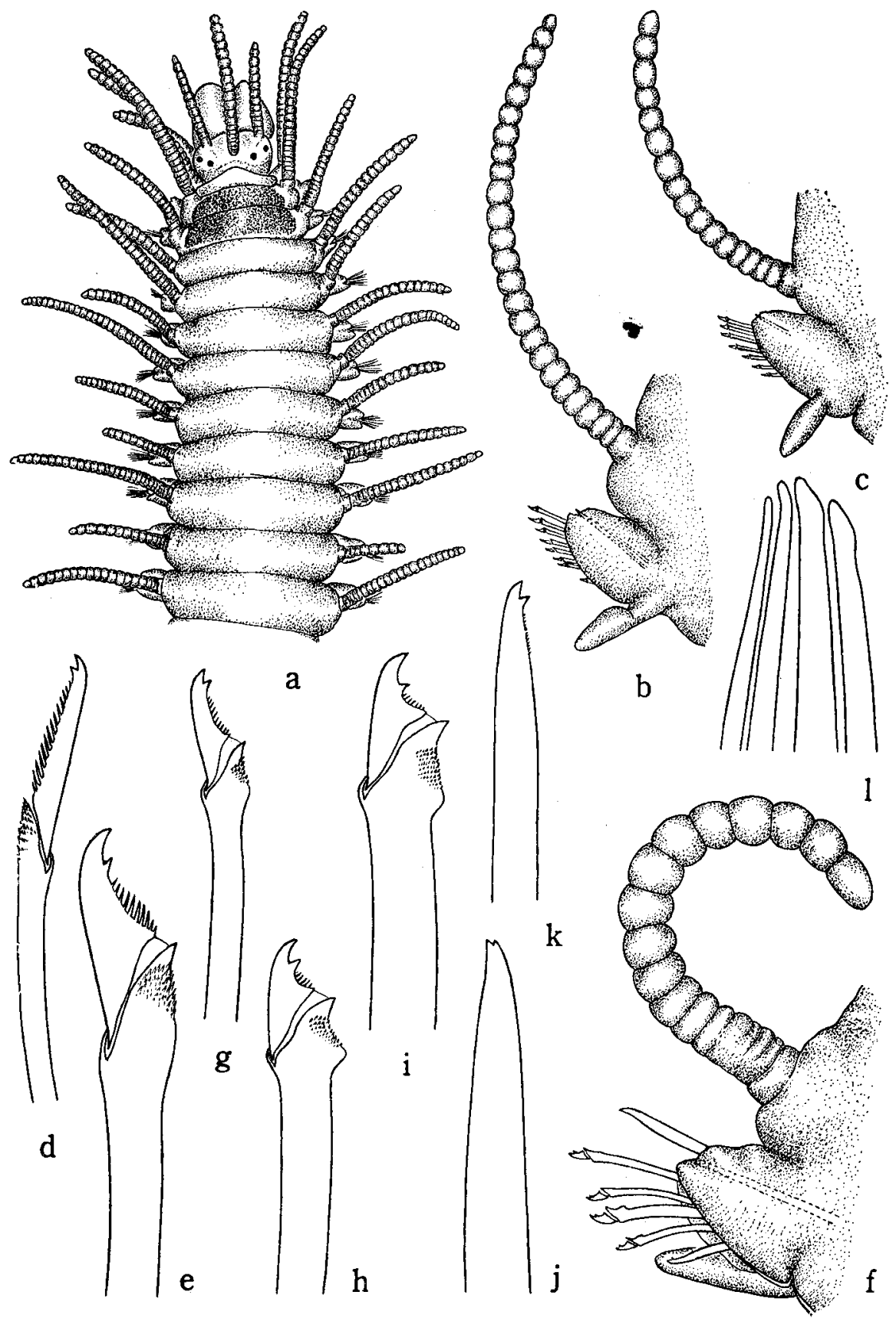

Text-fig. 63. Typosyllis monilata n. sp. a, anterior end, in dorsal view, $\times 32$; $b$, median parapodium with long dorsal cirrus, in posterior view, $\times 95 ; \mathrm{c}$, median parapodium with short dorsal cirrus, in same view, $\times 95$; $d$, superior compound seta from 1st parapodium, $\times 950$; e, compound seta from median parapodium, $\times 950 ; \mathrm{f}$, posterior parapodium, in anterior view, $\times 190$; $\mathrm{g}$, slender compound seta from posterior parapodium, $\times 950 ; \mathrm{h}$, i, thick compound setae from same parapodium, $\times 950 ; j$, superior simple seta from same parapodium, $\times 950 ; \mathrm{k}$, inferior simple seta from same parapodium, $\times 950 ; 1$, acicula from 1 st parapodium, $\times 950$. 


\title{
Typosyllis regulata $\mathrm{n}$. sp.
}

\author{
(Text-fig. 64, a-n)
}

Syllis (Ehlersia) cerina AUgener, 1913, pp. 209-211, pl. 3, fig. 40a, textfig. 25 (not GRube, 1878, p. 119).

Collection: Seto, in intertidal zone.

Description: The largest specimen measures $23 \mathrm{~mm}$ long and $1 \mathrm{~mm}$ wide including parapodia; it consists of 116 setigerous segments. The body is orange and has no color markings. The prostomium is wider than long and has two pairs of reddish eyes in trapezoidal arrangement (fig. a). A median antenna arises between the posterior eyes and is about 3 times as long as the prostomium; it has 25 annulations. Lateral antennae emerge from the anterior margin of the prostomium and each is about two-thirds as long as the median one. Palpi are subtriangular and are slightly longer than the prostomium; they are fused only at their bases. The pharynx is distally surrounded by 10 soft papillae and a middorsal tooth occurs in its inner wall; the distal part of the tooth extends slightly beyond the anterior margin of inner wall (fig. b). The proventriculus extends from setigerous segment 12 to 22 . The dorsal tentacular cirri are as long as the median antenna, and the ventral cirri are about half as long as the dorsal ones. The first dorsal cirri are about 1.5 times as long as the median antenna and each has 35 to 40 annulations. The second cirri are short, about half as long as the first one. More posterior dorsal cirri alternate in length; in median parapodia the short cirri are about as long as the body is wide, and the long cirri are slightly shorter than twice as long as the short ones; they have 23 (fig. c) and 40 annulations (fig. d), and each is slender. Parapodia are conical and have compound bidentate setae with serrations along the cutting margin; these setae are nearly uniform throughout. In anterior parapodia the superior appendages are slenderer and longer than those in inferior position; the serrations are less developed (figs. e, f). Those in median parapodia are thicker than those in front, and have a large, triangular secondary tooth; superior appendages are about twice as long as the inferior ones. The serrations along the cutting margin are well developed, most so in the middle setae of a fascicle, with the superior most serration reaching to the tip of the secondary tooth (figs. g, h, i). Setae of the posterior parapodia are again slenderer and the distal tooth of each appendage is slenderer than the secondary tooth (figs. j, k). In addition, two simple setae are present in superior and inferior positions of the fascicle; the first is entire at the tip (fig. 1) and the second has a subdistal triangular secondary tooth, and minute serrations along the one side (fig. m). Ventral cirri are digitate and extend beyond the tip of the setigerous lobe. Acicula number 3 in median parapodia and decrease gradually to one posteriorly; their tips are malletheaded (fig. $\mathrm{n}$ ). The pygidium has two long anal cirri.

Typosyllis regulata is characterized as follows: (1) the body is slender, thread-like and has no color markings; (2) dorsal cirri are slender and in the median region alternate long with 40 and short with 23 annulations; (3) the proventriculus extends 


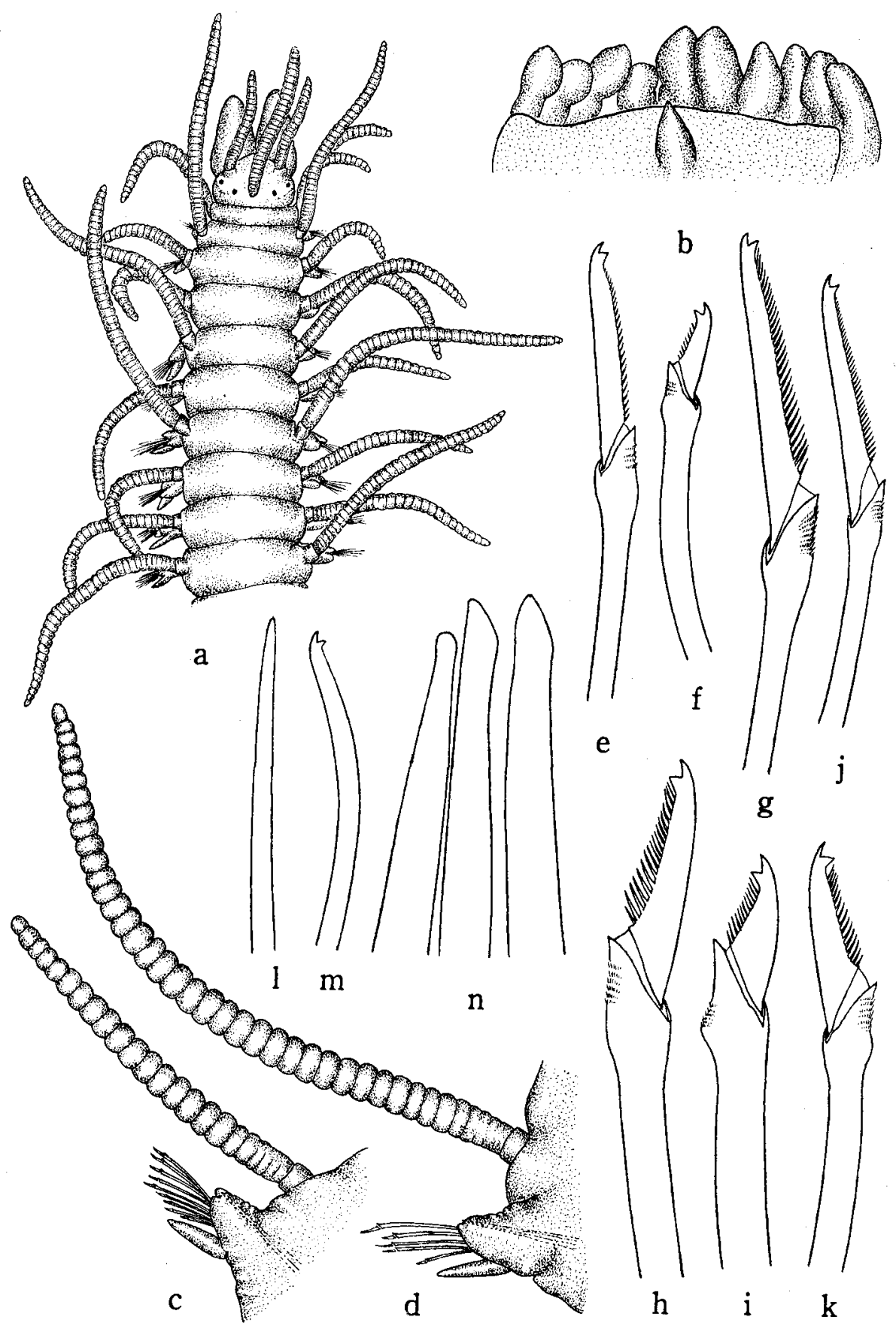

Text-fig. 64. Typosyllis regulata $n$. sp. a, anterior end, in dorsal view, $\times 32$; b, distal part of pharynx opened by dissection, $\times 95 ; \mathrm{c}$, median parapodium with short dorsal cirrus, in anterior view, $\times 65$; d, median parapodium with long dorsal cirrus, in same view, $\times 65$; e, superior compound seta from 1 st parapodium, $\times 950$; $f$, inferior compound seta from 
through 11 segments; (4) compound setae in a fascicle are uniform, longer in superior and shorter in inferior position, and with long serrations along the cutting margin of appendages and (5) two additional simple setae in posterior parapodia are distally pointed in superior and bifid in inferior positions.

T. regulata is similar to Typosyllis truncata (Haswell, 1920, p. 94) from Australia, in the features of the body, antennae, dorsal cirri and setae. T. truncala is distinguished from the first in that (1) the proventriculus extends through four to six, instead of 11 segments; (2) the superior simple seta of posterior parapodia is distally truncate, instead of spindled and the inferior simple seta from the same parapodium is short with pointed tip, instead of distinctly bifid with minute serrations along one side of the shaft.

T. regulata was compared with the holotype of Typosyllis harti (Berkeley and Berkeley, 1938, p. 35) from off the west coast of Vancouver, Canada, in $45 \mathrm{fms}$. The two are similar in the body and annulations of dorsal cirri. However, T. regulata is distinguished from T. harti as follows: (1) the first has mallet-headed or rounded acicula and the second has needlelike acicula, one of which is thick and its distal tip protrudes from the parapodium; (2) in the first each of the compound setae has a subtriangular, large secondary tooth and upper serrations of cutting margin are comparatively long, whereas the second has a small secondary tooth and short serrations.

A single, small specimen of Syllis (Ehlersia) cerina Augener (1913), (not Grube, 1878) from Australia was re-examined. It is $4 \mathrm{~mm}$ long and $0.4 \mathrm{~mm}$ wide including parapodia for 60 setigerous segments. Dorsal cirri in the median region of the body are distinctly articled and each has 12 to 20 annulations. In anterior parapodia the superior appendages are about twice as long as the inferior ones; these have a large, triangular secondary tooth and long serrations along the cutting margin; they are not spinigerous. Superior setal appendages in median parapodia are about 1.5 times as long as the inferior ones; each has a large, subdistal secondary tooth and long serrations. The appendages in the posterior parapodia are similar to those of the anterior ones, but the secondary tooth is more conspicuous. There are two additional simple setae (not one as Augener described); the superior seta is spindle-shaped and the inferior one bifid.

Japanese specimens are like Australian ones except for the length of the dorsal cirri; these differences may result from varying sizes of individuals.

Syllis (Ehlersia) cerina Augener (1913) differs from Syllis cerina Grube (1878) from Philippines in that the first lacks a spiniger in the superior position of the setal

same parapodium, $\times 950 ; \mathrm{g}$, superior compound seta from median parapodium, $\times 950$; h, median compound seta from same parapodium, $\times 950$; $i$, inferior compound seta from same parapodium, $\times 950 ; \mathrm{j}$, superior compound seta from posterior parapodium, $\times 950$ $\mathrm{k}$, median compound seta from same parapodium, $\times 950 ; 1$, superior simple seta from same parapodium, $\times 950 ; \mathrm{m}$, inferior bifid simple seta from same parapodium, $\times 950$; $\mathrm{n}$, acicula from median parapodium, $\times 950$. 
fascicle, whereas the second has 1 or 2 spinigers in superior position; the length of the appendages is 4 to 5 times that of the inferior falcigers.

Syllis $(E$.$) cerina Augener is referred to this new species.$

Distribution: Australia; southern Japan.

\section{Typosyllis variegata (GRUBE, 1860)}

Syllis (Typosyllis) variegata Haswell, 1920, pp. 91-92; Fauvel, 1923, p. 262, fig. 97 h-n; OKuda and YamadA, 1954, p. 182; Rullier, 1964, p. 161.

Typosyllis variegata Hartmann-Schröder, 1960, p. 75, pl. 4, figs. 16-20; Imajima and Hartman, 1964, pp. 137-138, pl. 34, figs. a-i.

Syllis variegata UsGHAKov and $\mathrm{WU}, 1962$, p. 59.

Collection: Shirikishinai; Hakodate; Matsumae; Rebun Island; Asamushi; Onagawa; Uraga Strait; Sugashima; Seto; Tamano; Mukaishima; Usa; Amakusa; Noto-ogi, in intertidal zone.

Diagnosis: The largest specimen measures $28 \mathrm{~mm}$ long and $1.3 \mathrm{~mm}$ wide including parapodia; it consists of 121 setigerous segments. The dorsum of anterior segments has irregular, light purple transverse bands on each segment; these diminish to a few color spots in median and posterior segments. The prostomium is broader than long; there are two pairs of eyes in trapezoidal arrangement and a pair of frontal eyes. A median antenna has 25 to 30 annulations and each of the lateral ones has 15 to 18 annulations. The pharynx terminates in 10 soft papillae and the inner wall has a middorsal tooth near its anterior margin. The proventriculus extends from segment $13-15$ to $22-27$, or through 10 to 13 segments. The dorsal cirri alternate long and short throughout; in median region they have 23 and 36 annulations. Setae are all bidentate composite, and the cutting margin has coarse serrations. Posterior parapodia have two additional simple setae in superior and inferior positions; both are distally bifid with minute serrations on one side. Acicula number 5 to 2 in a parapodium.

Distribution: Western and southern Europe; Mediterranean Sea; Australia; Indo-Pacific areas; southern California; Bering Sea; Yellow Sea; Japan.

\section{Typosyllis prolifera (KROHN, 1852)}

(Text-fig. 65, a-n)

Syllis (Typosyllis) prolifera FAUveL, 1923, pp. 261-262, fig. 97, a-g; 1953, pp. 149-150, fig. 74, a-g; Rullier, 1963, p. 184.

Text-fig. 65. Typosyllis prolifera (KROHN). a, anterior end, in dorsal view, $\times 30$; b, distal part of pharynx opened by dissection, $\times 42$; $c$, median parapodium with long dorsal cirrus, in posterior view, $\times 67$; $d$, median parapodium with short dorsal cirrus, in same view, $\times 67$; e, superior compound seta from 7 th parapodium, $\times 840 ; f$, inferior compound seta from same parapodium, $\times 840$; g, superior compound seta from median parapodium, 


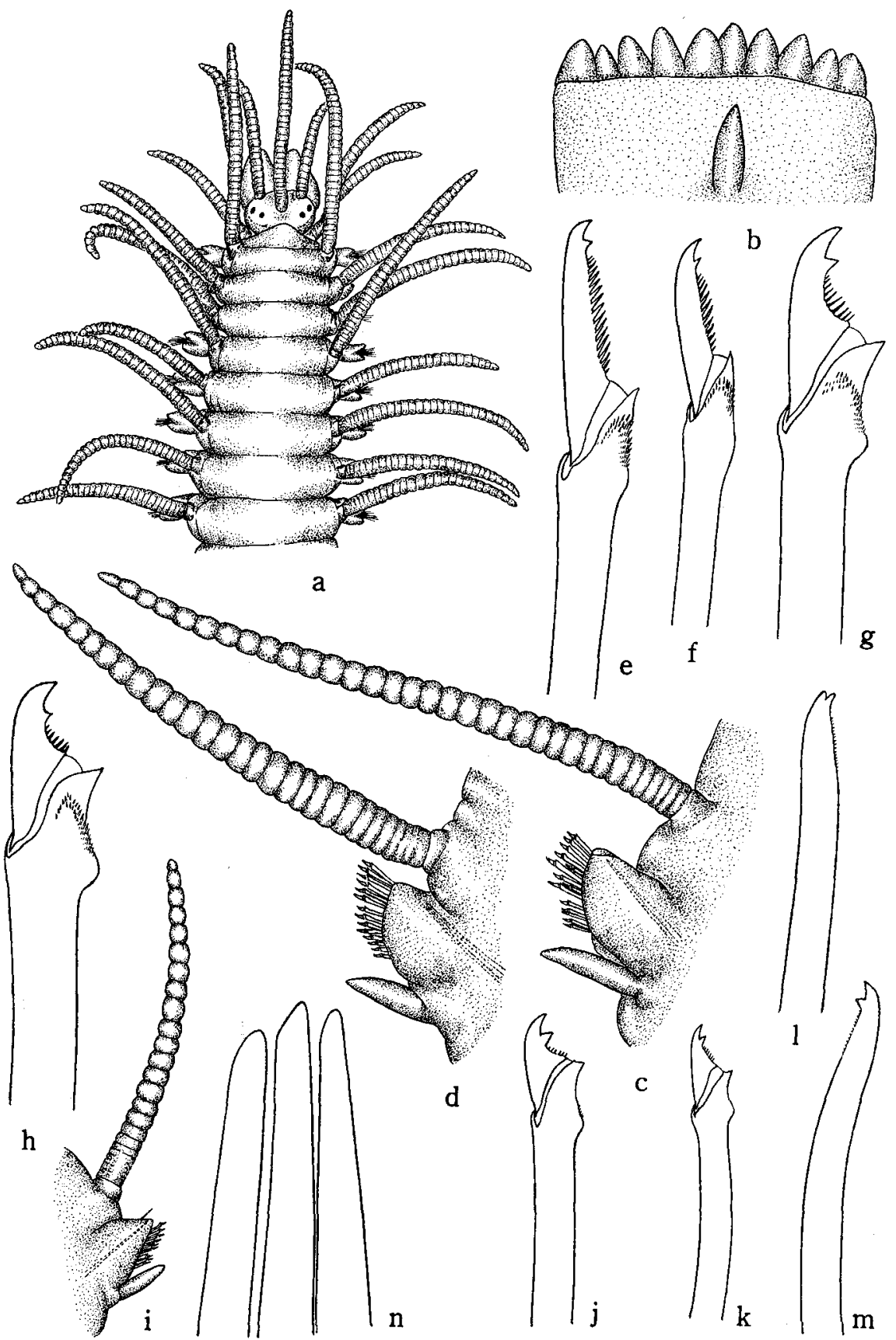

$\times 840 ; \mathrm{h}$, inferior compound seta from same parapodium, $\times 840 ; \mathrm{i}$, posterior parapodium, $\times 95 ; \mathrm{j}, \mathrm{k}$, compound setac from posterior parapodium, $\times 840 ; \mathrm{l}$, superior simple seta from same parapodium, $\times 840 ; \mathrm{m}$, inferior simple seta from same parapodium, $\times 840 ; \mathrm{n}$, acicula from median parapodium, $\times 640$. 
Collection: Asamushi; Misaki; Sugashima; Seto; Mukaishima; Amakusa; Usa; Noto-ogi, in intertidal zone.

Description: The largest specimen measures $35 \mathrm{~mm}$ long and $1.7 \mathrm{~mm}$ wide including parapodia; it consists of 98 setigerous segments. The dorsum is purplish brown and has no markings. The ventral side of the body, palpi and prostomium except the anterior part are yellow. The prostomium is broader than long and has two pairs of reddish eyes in trapezoidal arrangement (fig. a). The anterior eyes are slightly the larger. Palpi are subtriangular and fused at their bases; they are about as long as the prostomium. The pharynx terminates in 10 soft papillae and has a spindlelike, subterminal tooth (fig. b). The proventriculus extends from setigerous segment $10-11$ to $14-15$, or through 5 to 6 segments. A median antenna arises from the center of the prostomium and is about five times as long as the prostomium; it has 35 annulations. Lateral antennae emerge from the anterior margin of the prostomium and are about two-thirds as long as the prostomium. The dorsal side of the tentacular segment is triangular. The dorsal tentacular cirri are about four times as long as the prostomium, each with 33 to 36 annulations. The first dorsal cirri are about as long as the median antenna, with 32 to 34 annulations. The second cirri are about three-fourths as long as the first ones. On more posterior segments dorsal cirri alternate long, with 34 to 37 annulations (fig. c), and short with 30 to 33 (fig. d). The long cirri are about as long as the body is wide. Parapodia are bluntly conical and have a fascicle of bidentate compound setae. The appendages of anterior setae is long, slender with coarse serrations (fig. e) along the cutting margin; superior ones are longer than inferior ones (fig. f). Setae in median parapodia are thicker than those anterior and have short appendages with a large secondary tooth; superior one (fig. $g$ ) is slightly longer than the inferior one (fig. $h$ ). A posterior parapodium has a slender dorsal cirrus with 20 to 24 annulations, and a fascicle of composite and two simple setae (fig. i). Posterior compound setae are slenderer than these in median segments, with a larger secondary tooth (figs. j, k). Two additional simple setae occur, one in superior and one in inferior position of a fascicle; the superior one is distally bifid and has minute serrations along one side of the shaft (fig. l) and the inferior one is distally curved and has a triangular, subdistal secondary tooth (fig. $\mathrm{m}$ ). Acicula number three in a median parapodia (fig. $n$ ) and decrease to one posteriorly. Ventral cirri are digitate and do not extend beyond the tips of the setigerous lobes.

Typosyllis prolifera is closely allied to $T$. variegata in the features of dorsal cirri and compound setae. T. prolifera may be distinguished from $T$. variegata as follows: (1) the dorsum of the first is purplish brown and has no color markings, instead of irregular, light purple transverse bands, and (2) the first has a proventriculus extending through 5 to 6 , instead of 10 to 13 segments.

The species is new to Japan.

Distribution: Mediterranean Sea; Atlantic and Indian Oceans; Japan.

( $T_{0}$ be continued.) 